\title{
The extinct Nerineoidea and Acteonelloidea (Heterobranchia, Gastropoda): a palaeobiological approach
}

\author{
Heinz A. KOLLMANN \\ Naturhistorisches Museum Wien, \\ 1010 Wien, Burgring 7 (Austria) \\ heinz.kollmann@nhm-wien.ac.at
}

Kollmann H. A. 2014. - The extinct Nerineoidea and Acteonelloidea (Heterobranchia, Gastropoda): a palaeobiological approach. Geodiversitas 36 (3): 349-383. http://dx.doi. org/10.5252/g2014n3a2

KEY WORDS

Nerineoidea, Acteonelloidea, Heterobranchia, Gastropoda, Mesozoic, functional morphology, ecology,

diets and feeding, phylogeny, extinction, new family.

\begin{abstract}
Based on the morphology of the aperture and internal plaits or folds, the Nerineoidea Zittel, 1873 are subdivided into seven families: the Pseudonerineidae Pchelintsev, 1965, Ceritellidae Wenz, 1940, Nerinellidae Pchelintsev, 1960, Eunerineidae n. fam. (new family that includes the Nerineidae Zittel, 1873 (pars) and the Diptyxidae Bouchet \& Rocroi, 2005) the Ptygmatididae Pchelintsev, 1960, Nerineidae and Itieriidae Cossmann, 1896. The internal plaits of the Nerineoidea had different functions: the columellar plaits subdivided the columellar muscle into strands, which allowed portions of the foot to be moved individually. A tubelike space delimited by the parietal and palatal plaits is compared with the pallial caecum or posterior mantle chamber of heterobranchs and served the respiration. Waste from both mantle chambers was expelled through a subsutural notch, which is the common feature of the Nerineoidea. The Nerineoidea were shell draggers and probably deposit feeders with a semi- infaunal mode of life. The "Lower Heterobranchia" represented by the Streptacidoidea Knight, 1931, Nerineoidea and Acteonelloidea Akopjan, 1976 cluster outside the Euthyneura Knight, 1931. The Acteonelloidea, the second group of large Heterobranchia are related to the Nerineoidea and cannot be part of the Acteonoidea. The extinction of the Eunerineidae n. fam., the Ptygmatididae and Ceritellidae in the Late Cenomanian was caused by a general warming in low latitudes. The Acteonellidae genus Trochactaeon Meek, 1863 replaced the extinct Eunerineidae n. fam. ecologically in shallow marine soft-bottom environments and became extinct itself in the Lower Campanian due to the general cooling. In the Caribbean palaeobiological province, the endemic Nerineoidea genus Plesioptygmatis Boese, 1906 extended stratigraphically to the basal Late Maastrichtian. Acteonella d'Orbigny, 1842 and the endemic Acteonellidae genus Mexicotrochactaeon Akopjan, 1972 ranged upwards into the Late Maastrichtian.
\end{abstract}




\author{
MOTS CLÉS \\ Nerineoidea, \\ Acteonelloidea, \\ Heterobranchia, \\ Gastropoda, \\ Mésozoïque, \\ morphologie fonctionelle, \\ écologie, \\ régime alimentaire \\ et mécanisme \\ d'alimentation, \\ phylogénie, \\ extinction, \\ famille nouvelle.
}

\section{RÉSUMÉ}

Les Nerineoidea et Acteonelloidea fossiles: une approche paléobiologique des Heterobranchia géants éteints (Gastropoda).

Sur la base de la morphologie de l'ouverture et des plis internes, les Nerineoidea Zittel, 1873 sont subdivisés en sept familles : les Pseudonerineidae Pchelintsev, 1965, Ceritellidae Wenz, 1940, Nerinellidae Pchelintsev, 1960, Eunerineidae n. fam. (nouvelle famille incluant les Nerineidae Zittel, 1873 (pars) et les Diptyxidae Bouchet \& Rocroi, 2005) les Ptygmatididae Pchelintsev, 1960, Nerineidae et Itieriidae Cossmann, 1896. Les plis internes des Nerineoidea avaient différentes fonctions : les plis columellaires subdivisaient le muscle columellaire en bandes, qui permettaient à différentes portions du pied de bouger individuellement. Un espace en forme de tube délimité par les plis pariétaux et palataux est comparable avec le cæcum palléal ou la chambre postérieure du manteau chez les hétérobranches et servait à la respiration. Les rejets des deux chambres du manteau étaient expulsés à travers une encoche structurelle, qui est un trait commun des Nerineoidea. Les Nerineoidea étaient des organismes porteurs de coquille et probablement limivores avec un mode de vie semi-enfoui. Les « hétérobranches inférieurs » représentés par les Streptacidoidea Knight, 1931, Nerineoidea et Acteonelloidea Akopjan, 1976 forment un groupe distinct des Euthyneura Knight, 1931. Les Acteonelloidea, le second groupe de grands Heterobranchia, sont parents des Nerineoidea et ne peuvent pas faire partie des Acteonoidea. L'extinction des Eunerineidae n. fam., des Ptygmatididae et Ceritellidae au Cénomanien supérieur a été causée par un réchauffement général en basses latitudes. Le genre d'Acteonellidae Trochactaeon Meek, 1863 a remplacé écologiquement les Eunerineidae n. fam. éteints dans les environnements peu profonds à substrat mou et a disparu lui-même au Campanien inférieur en raison d'un refroidissement général. Dans la province paléobiologique des Caraïbes, le genre de Nerineoidea Plesioptygmatis Boese, 1906 s'étend stratigraphiquement jusqu’à la base du Maastrichtien supérieur. Acteonella d'Orbigny, 1842 et le genre d'Acteonellidae endémique Mexicotrochactaeon Akopjan, 1972 ont persisté plus haut dans le Maastrichtien supérieur.

\section{INTRODUCTION}

The extinct Nerineoidea Zittel, 1873 were widely distributed in low-latitude shallow marine realms during Jurassic and Cretaceous times (Dietrich 1925; Sohl 1969, 1987). Besides their large shells, the limitation of the internal space by prominent wall protrusions has stimulated interest in their function for almost 200 years. The present study focuses on evaluating the morphological characters of the exclusively extinct Nerineoidea by comparison with extant heterobranchs. Because of taxonomic and systematic incongruences, the families and subfamilies are re-defined at the beginning. In the final sections the systematic position of both the Nerineoidea and the Acteonelloidea Akopjan, 1976, which constitute the other group of large Mesozoic heterobranchs, and their extinction are discussed.

GENERAL OUTLINE OF NERINEOIDEA MOPHOLOGY Protoconch

Due to sediment transport in siliciclastic environments and diagenetic alteration in carbonatic environments, protoconchs are only rarely preserved. Bigot (1896) was the first to figure the heterostrophic protoconch of a Pseudonerinea Loriol, 1890 taxon. The protoconch, characterized as paucispiral by that author, apparently consists of a single, sinistrally 


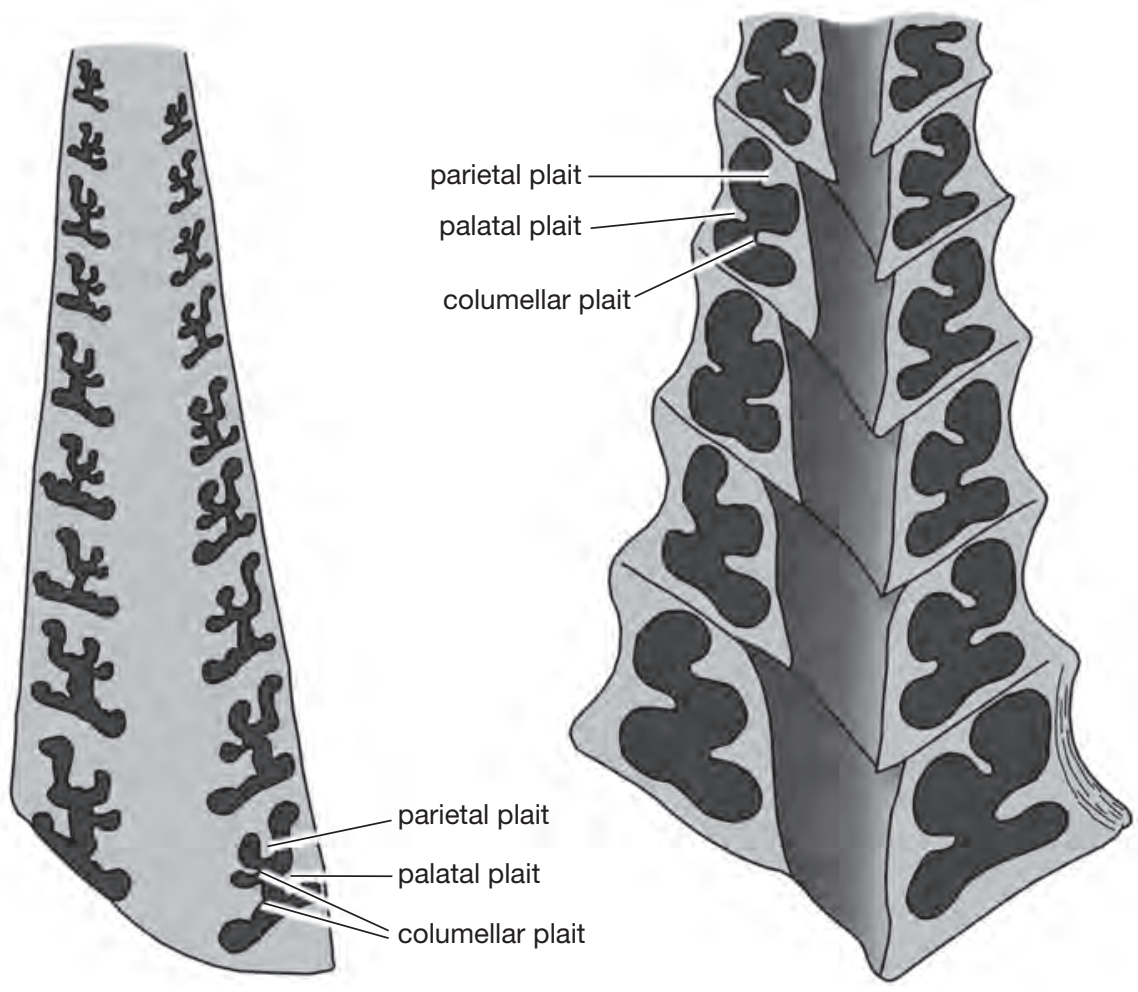

FIG. 1. - Terminology of internal plaits (modified from Cox 1964).

coiled smooth whorl. Heterostrophic protoconchs have also been reported by Huckriede (1967) in Late Jurassic Ceritellidae Wenz, 1940 but have not been figured or described. Protoconchs of Eunerineidae n. fam. shells recorded by Vaughan (1988) and Kowalke \& Bandel (1996) consist of a single smooth whorl and their axis forms an angle of $80-90^{\circ}$ with that of the teleconch. In both cases, the diameter of the protoconch is $2.2 \mathrm{~mm}$. Gründel (2006) has shown a Nerinella Sharpe, 1850 species of the same size with a deviation of $90^{\circ}$ to the teleconch axis. The uniformity of the Nerineoidea protoconch was emphasized by Vaughan (1988).

\section{Teleoconch}

Following Voltz (1836), who was first to provide a comprehensive description of Nerineoidea morphology, Cossmann (1896) referred to the adapical reflection of the margin of the labrum to a subsutural notch as a common feature of this group.
Internal wall protrusions of the Nerineoidea are commonly known as folds or plaits. According to the positions of the plaits, a distinction is made between columellar, parietal, palatal and basal plaits (Fig. 1). Barker (1990) pointed out that these structures were deposited at the interface between the mantle and the shell and have nothing in common with traditional plaits, folds or plications. Despite this fact, the term is used here according to the general practice.

\section{SysteMATIC POSITION}

Systematics is not the primary purpose of this paper, but changes in allocations and taxonomic insecurities make this chapter necessary for further understanding.

Cossmann (1896) established the suborder Entomotaeniata, which included the families Tubiferidae (= Ceritellidae Wenz, 1940), Nerineidae Zittel, 1873 and Itieriidae Cossmann, 1896. Common to these groups is the narrow subsutural notch, which Voltz 
(1836) recognized first as the connecting morphological feature. Cossmann (1896) and Wenz (1940) assumed a systematic position between the Cerithioidea Fleming, 1822 and the Pyramidellidae and classified the Nerineoidea as Prosobranchia. In contrast to earlier allocations, Pchelintsev (1965) merged the Nerineoida with the Vetigastropod superfamily Murchisonoidea to the order Murchisoniata.

Since Haszprunar (1985a), Vaughan (1988) and Bandel (1994a, 1996), the systematic position of the Nerineoidea within the Heterobranchia is no longer a subject of discussion. Haszprunar (1985a) and Bandel (1994a, 1996) assigned them to the Allogastropoda or "primitive" Heterobranchia (whatever this discriminating term means).

\section{SYSTEMATIC HIERARCHIES}

Sirna (1995) compiled the earlier taxonomic subdivisions on the family and genus level which are therefore not discussed in detail. Note that Pchelintsev (1965) and Lyssenko \& Korotkow (1992) split the group into extremely narrow-defined families, which they arranged in four superfamilies: Tubiferoidea, Nerinoidea, Nerinelloidea and Itierioidea (endings changed according to current use). This taxonomic subdivision, which was also adopted by by Ponder \& Waren (1988), necessitates upgrading the highest taxonomic level to suborder status, which is unreasonable (see Vaughan 1988).

The taxonomic subdivision applied in this paper follows, with minor changes, a concept proposed by Kollmann in Bouchet \& Rocroi (2005: footnote 185). It arranges the Nerineoidea in seven families which are discussed below. The following criteria for a hierarchic system are applied:

- superfamily: turriculate to oviform shell; subsutural notch;

- families: base of last whorl, siphonal apparatus;

- genera: internal plication, whorl outline;

- species: external sculpture.
Generally, variations in the shape and size of internal plaits, which frequently have been used to distinguish species, are not suitable criteria. Changes with ontogeny, variability and even different cutting planes or differences in preservation obscure actual plait size and shape. Nevertheless, sectioned nerineoid shells remain an important approach for determining the generic position and are therefore valuable for palecological and even biostratigraphical purposes (Krivic 1974; Wieczorek 1979; Kollmann et al. 2003; Waite et al. 2008).

\section{ACRONYMS}

MNHN.F Collection of the Muséum national d'Histoire naturelle, Paris, Départment Histoire de la Terre;

NHMW Collection of the Museum of Natural History Vienna (Austria), Department of Geology and Palaeontology.

\section{SYSTEMATIC SUBDIVISION OF THE NERINEOIDEA}

\section{Superfamily NeRINEOIDEA Zittel, 1873}

Nerineoidea Zittel, 1873: 328.

SUPERFAMILY CHARACTERS. - Shells turriculate to oviform, of medium size to large. Whorls concave to moderately convex. Growth lines adapically reflected. Aperture with expanded inductura, narrow subsutural notch and siphonal notch or canal; plaits, if present, most prominent before the final $1 \frac{1}{2}$ whorls, decreasing in size towards aperture.

\section{Family Pseudonerineidae Pchelintsev, 1965}

(Fig. 2A)

Pseudonerineidae Pchelintsev, 1965: 14 (pars).

Tubiferidae Cossmann, 1896: 12 (pars).

FIG. 2. - Pseudonerineidae Pchelintsev, 1965, Ceritellidae Wenz, 1940 : A, Pseudonerinea clytia (d'Orbigny, 1851), Middle Oxfordian, Cordebugle (Calvados, France), MNHN.F.A46317; B, Cossmannea desvoidyi (d'Orbigny, 1850), Middle Oxfordian, St.-Mihiel (Meuse, France), paralectotype MNHN.F.A08287; C, Cossmannea desvoidyi, axial section, Middle Oxfordian, St.-Mihiel (Meuse, France), MNHN.F.A08287; D, Cossmannea esparcyensis (Piette, 1855), Bathonian, Esparcy (Aisne, France), figure from Fischer 1969, MNHN.F.R00146; E, Cossmannea speciosa (Voltz, 1835), Oxfordian, Ecuelly (Haute Saone, France), figure from Maire 1927, MNHN.F.A26131; F, Fibuloptyxis bucillyensis Fischer, 1959, axial section, Bathonian, Bucilly (Aisne, France), MNHN.F.A24495; G, Fibuloptyxis bucillyensis, with well-preserved aperture, Bathonian, Bucilly (Aisne, France), MNHN.F.A49007; H, Fibuloptyxis undans Piette, 1857, the figure shows the subsutural notch, Bathonian, 


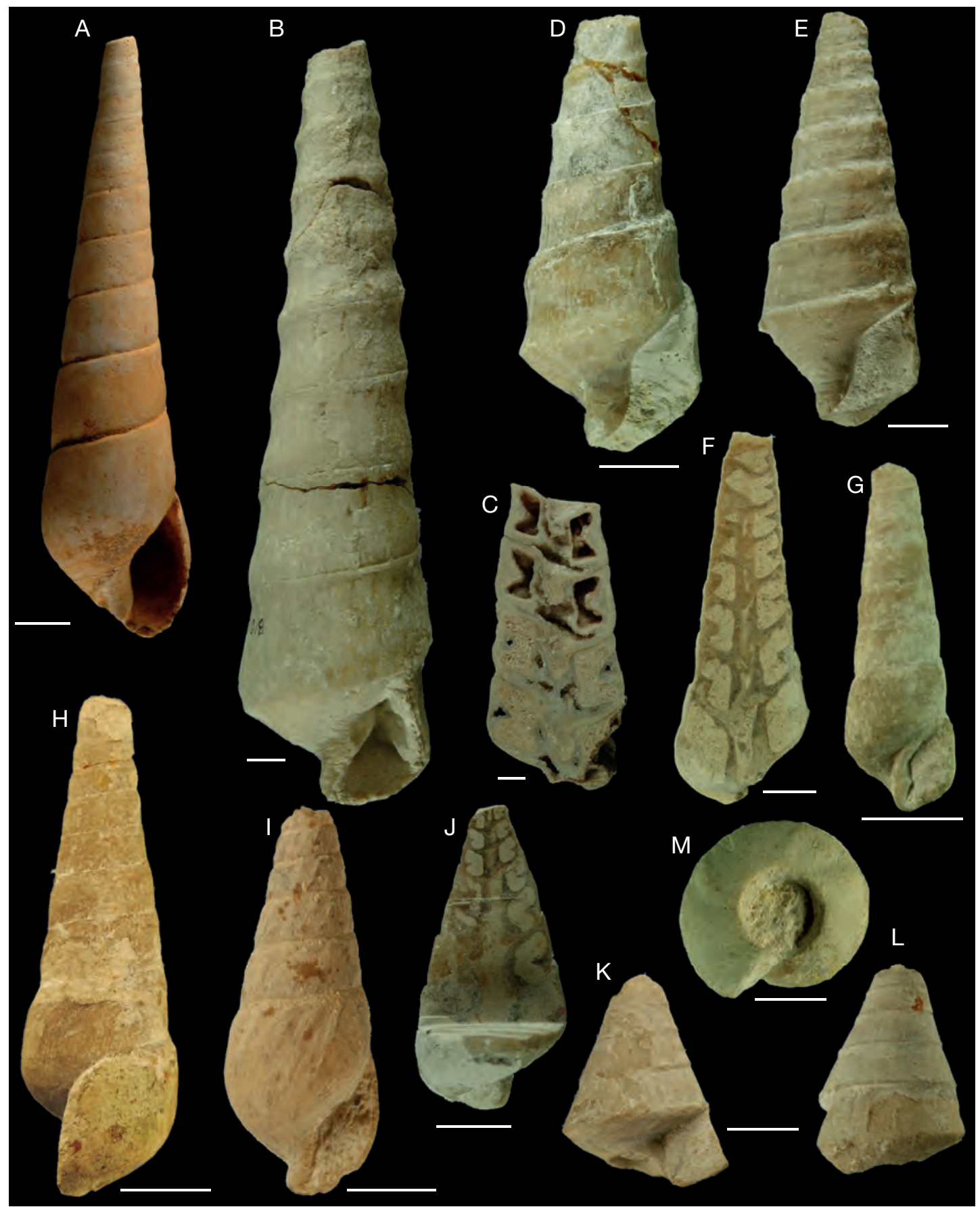

Eparcy (Aisne, France), MNHN.F; I, Fibuloptyxis undans, Bathonian, Eparcy (Aisne, France), MNHN.F.A50556; J, Fibuloptyxis elegans convexa Fischer, 1960, Bathonian, Eparcy (Aisne, France), holotype MNHN.F.A24494; K, L, Aphanoptyxis munieri (Rigaux \& Sauvage, 1868), Bathonian, Bucilly (Aisne, France), MNHN.F.A49001; M, Aphanoptyxis munieri, base of specimen figured by Fischer 1969, Bathonien, Bucilly (Ardennes, France), MNHN.F.R00255. Scale bars: $10 \mathrm{~mm}$. 
TYPe Genus. — Pseudonerinea de Loriol, 1890 (1890: 81).

Type SPeCies. — P. blauensis de Loriol, 1890 (1890: 11).

FAMILY CHARACTERS. - Shell narrow turriculate. Whorls flat to moderately convex. Aperture drop-shaped, basal excavation of aperture broad but shallow. Columella straight, without internal plaits.

\section{REMARKS}

The broadly excavated base of Pseudonerinea clytia (d'Orbigny, 1851) (Fig. 2A) is typical for Pseudonerineidae, whereas the Ceritellidae possess a deep basal notch. Because of these differences, which suggest different life habits, the two groups are considered as separate families in contrast to earlier taxonomic subdivisions .

Family Ceritellidae Wenz, 1940

(Fig. 2B-M)

Ceritellidae Wenz, 1940: 817. — Pchelintsev 1965: 9. (pars).

Tubiferidae Cossmann, 1896: 12 (pars).

Diptyxisidae Pchelintsev, 1965: 79

TyPe GENUS. — Ceritella Morris \& Lycett, 1854 [1854: 37].

TyPE SPECIES. — C. acuta Morris \& Lycett, 1854 [1854: 37]).

FAMILY CHARACTERS. - Shells medium size to large, broad turriculate or high oviform. Whorls convex, smooth or with collabral or spiral sculpture (in Proceritella Fischer, 1961). Periphery of last whorl rounded to angular, narrow umbilicate or anomphalous. Aperture semicircular, with siphonal notch, forming a siphonal aureole in umbilicate taxa and a beak in others. Small columellar plait disappearing towards aperture, restricted to the aperture in Fibuloptyxis bucillyensis Fischer, 1959. Strong palatal plait or parietal plait.

\section{REMARKS}

Cossmann (1895a) considered Ceritella as synonymous with Tubifer Piette, 1856. In the latter, the aperture is higher and a distinct subsutural ramp is developed. It therefore represents a different genus (see Gründel \& Nützel 2012).

Figure 2B-I demonstrates the high diversity of this family. It comprises taxa with more or less broad turriculate shells (Fibuloptyxis Cossmann, 1898; Proceritella Fischer, 1961) or with strongly inflated final whorls (Pseudotrochalia Cox, 1954).

Diptyxis Oppenheim, 1889 is allocated to the Ceritellidae because of its siphonal notch and the internal plication with its large parietal plait and a small columellar plait. The periphery is rounded angular to angular. The genus was established by Oppenheim (1889), who figured a fragment from the island of Capri under Nerinea (?Diptyxis) biplicata (the question mark is part of the original identification). Oppenheim neither discussed the new subgenus nor did he comment on the question mark. Actually, Oppenheim's species is a younger synonym of Nerinea bidentata Gemmelaro, 1865. There is no reason to retain the family Diptyxidae Pchelintsev, 1965 (described as "Diptyxisidae" by that author) with Nerinea csaklyana Herbich, 1886 as type species.

Extreme by its size is the type species of Cossmannea Pchelintsev, 1931, C. desvoidy (d'Orbigny, 1851) (Fig. 2B, C; see also Wieczorek 1979). Originally assigned to Nerinea Deshayes, 1827, Cossmannea possesses a rounded angular whorl periphery, a broad palatal plait and lacks a siphonal canal. It must therefore be allocated to the Ceritellidae. Most of the taxa allocated in the literature to Cossmannea, however, remain within the Eunerineidae n. fam. Despite its trochiform shell, which made Cossmann (1898) doubt its systematic position in the Nerineoidea, the aperture identifies Aphanoptyxis Cossmann, 1896 (synonymous: Endiatrachelus Cossmann, 1898, see Fischer 1969) as a genuine Ceritellidae taxon. In the type species, $A$. pellati Cossmann, 1898, the aperture is incomplete and the base appears to be rounded. Complete specimens show the basal notch (Fig. 2K-M).

FIG. 3. - Ptygmatididae Pchelintsev, 1960: A, Ptygmatis nodosa (Voltz, 1835) (= Pt. ferruginea Cossmann, 1898), Oxfordian, Vieil-St.Remy (Ardennes, France), MNHN.F.B12828; B, Bactroptyxis trachea (Deslongchamps, 1841), Bathonian, Rumigny (Ardennes, France), MNHN.F.A49008; C, Cryptoplocus salomoniana Cotteau, 1854, Kimmeridgian, Thury (Yonne, France), MNHN.F.R00331; D, E, Ptygmatis carpathica (Zeuschner, 1849), Kimmeridgian, La Combe de Vaux (Ain, France), MNHN.F.A49002; F, Bactroptyxis trachea, Late Bathonian, Poix (Ardennes, France), MNHN.F.A49009; G, Pchelintsevia salinensis (d'Orbigny, 1850), Portlandian, Doubs (France); NHMW 1874-LI864; H, Ptygmatis pseudobruntrutana (Gemmelaro, 1865), axial section, recrystallized shell partly preserved, Kimmeridgian, Ernstbrunn 


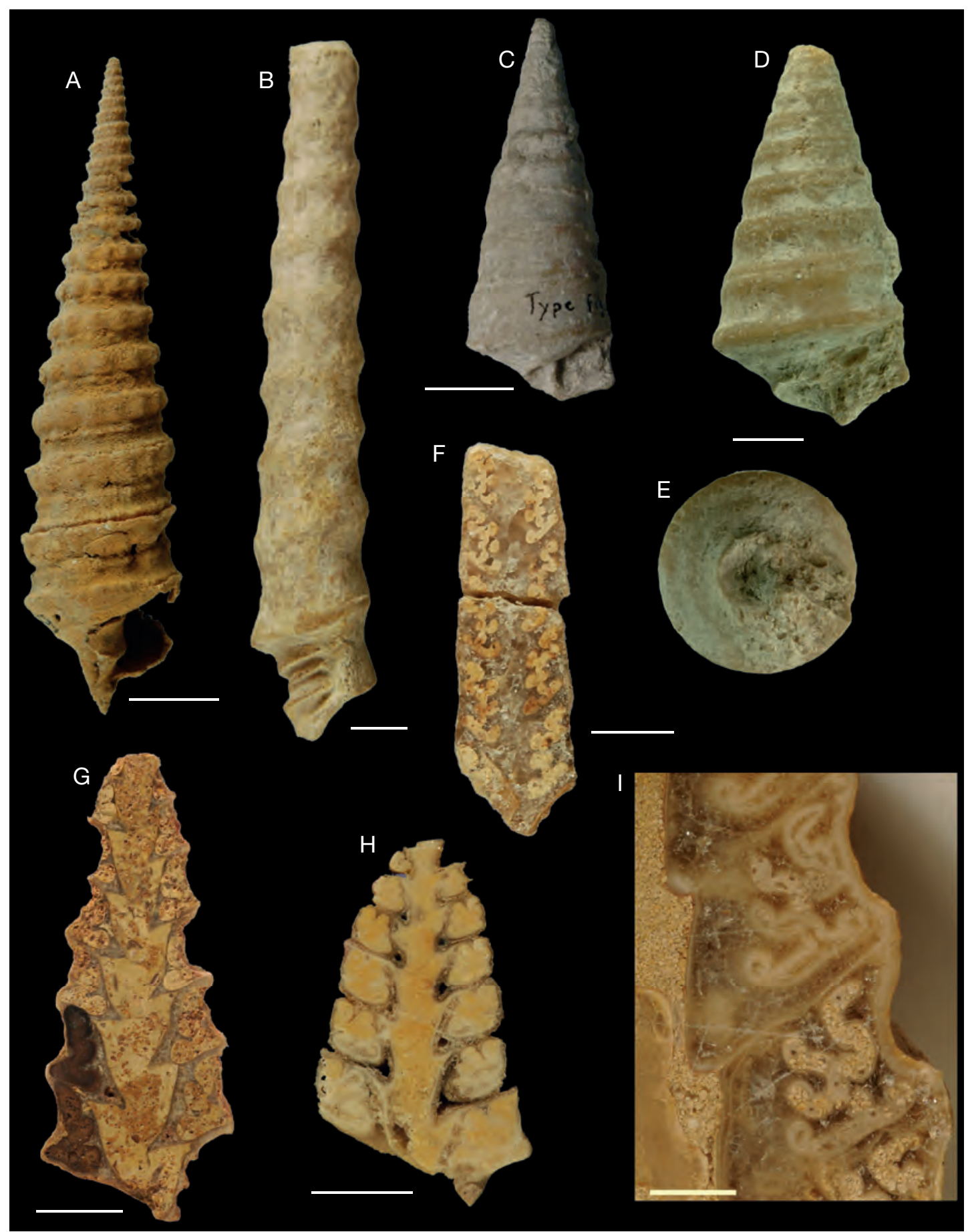

(Austria), NHMW 2013/0266/0001; I, Ptygmatis bruntrutana (Thurmann, 1832), enlarged whorl section showing cross sections through the duct system, Kimmeridgian, Alenquer (Portugal); NHMW 1869-X-30. Scale bars: A, D, H, 5 mm; B, C, E-G, I, 10 mm. 
Family Ptygmatididae Pchelintsev, 1960 (Fig. 3A-I)

Ptygmatisidae Pchelintsev, 1960: 51.

Ptygmatisinae Pchelintsev, 1960: 51.

Included subfamilies. - Ptygmatidinae Pchelintsev, 1960, Umboneinae Lyssenko \& Aliev, 1987 and Cryptoplocinae Pchelintsev, 1960 (see Kollmann \& Peza 1997a).

FAMILY CHARACTERS. - Whorls rhombic to triangular in cross section with siphonal notch. Columella hollow to solid. Two columellar plaits extending to detached columellar inductura. Parietal and palatal plait developing inside last whorl, thin and protruding strongly into the whorl interior. External end of plaits inflated, truncated or bifurcate in earlier whorls, incisions between columellar plaits deep and bent.

Subfamily Ptygmatidinae Pchelintsev, 1960 (Fig. 3A, B, I)

Ptygmatidinae Pchelintsev, 1960: 51.

Bactroptyxisidae Pchelintsev, 1965: 96.

Type Genus. — Ptygmatis Sharpe, 1850 (1850: 104).

TYPE SPECIES. - Pt. bruntruntana Thurmann, 1832 (1832: 17).

SUBFAMILY CHARACTERS. - Broad umbilicate to anomphalous. Whorls flat to moderately concave, rhombic in cross section. Two columellar plaits extending to detached columellar inductura. Parietal and palatal plait thin in the last whorl. External end of plaits inflated, truncated or bifurcate in earlier whorls, incisions between columellar plaits deep and bent.

\section{REMARKS}

The internal plaits are delicate in the final whorl but may become increasingly complex by the deposition of additional shell material in earlier whorls (Fig. 3F, I). According to Wieczorek (1998) all transitions are visible, even on the species level. Hudlestone (1889) records Ptygmatidinae taxa from the Inferior Oolite (Middle Jurassic) ranging in outline between slender and moderately broad. The increase of the apical angle accompanies a broadening of the columella cavity. The transitions are fluent and there is no reason to distinguish the Bactroptyxisidae Pchelintsev, 1965 upon species with solid columellas.

\section{Subfamily UMBONEINAE \\ Lyssenko \& Aliev, 1987}

(Fig. 3G)

Umboneidae Lyssenko \& Aliev, 1987: 117

Type Genus. — Umbonea Pchelintsev, 1965 (1965: 85).

Type sPeCIEs. - Nerinea dilatata d'Orbigny, 1852 (1852: 146).

SUBFAMILY CHARACTERS. - Shells with hollow columella; whorls almost triangular in outline, siphonal notch located on acute extension of aperture. The columellar, parietal and palatal plaits are small. The umbilicus may be covered by a thin lamella.

\section{REMARKS}

This group is assigned to the Ptygmatididae because of the typical siphonal portion which protrudes at about $60^{\circ}$ into the umbilicus. It has been named Diozoptyxisidae by Pchelintsev (1965). Diozoptyxis Cossmann, 1907 belongs, in fact, to the Campaniloidea (see Kollmann \& Peza 1997a; Kollmann 2005). Ptygmatididae species originally assigned to this family are allocated to the Umboneinae Lyssenko \& Aliev, 1987.

\section{Subfamily Cryptoplocinae Pchelintsev, 1960} (Fig. 3C-E, H)

Cryptoplocusidae Pchelintsev, 1965: 69.

FIG. 4. - Nerinellidae and Eunerineidae n. fam.: A-C, Nerinella grossouvrei Cossmann, 1896, Hettangian, Simon-la-Vineuse (Vendée, France); A, lectotype, with complete broad basal notch, MNHN.F.R00179; B, shell partly removed showing the internal plaits, MNHN.F.A49006; C, shell with moderately concave whorls, MNHN.F.A51317; D, Nerinella danusensis d'Orbigny, 1852, figure from Cossmann 1896, Oxfordian, Châtel-Censoir (Yonne, France), MNHN.F.R50376; E, Nerinella elatior (d'Orbigny, 1850), internal mould, figure from Cossmann 1896, Oxfordian, La Rochelle (Charente Maritime, France), MNHN.F.J08541; F, G, Aptyxiella flexuosa (Sowerby, 1831), Late Cretaceous, Russbach (Salzburg, Austria); F, NHMW 2013/0265/0002; G, axial section, NHMW 2013/0265/0001; H, Neri- 


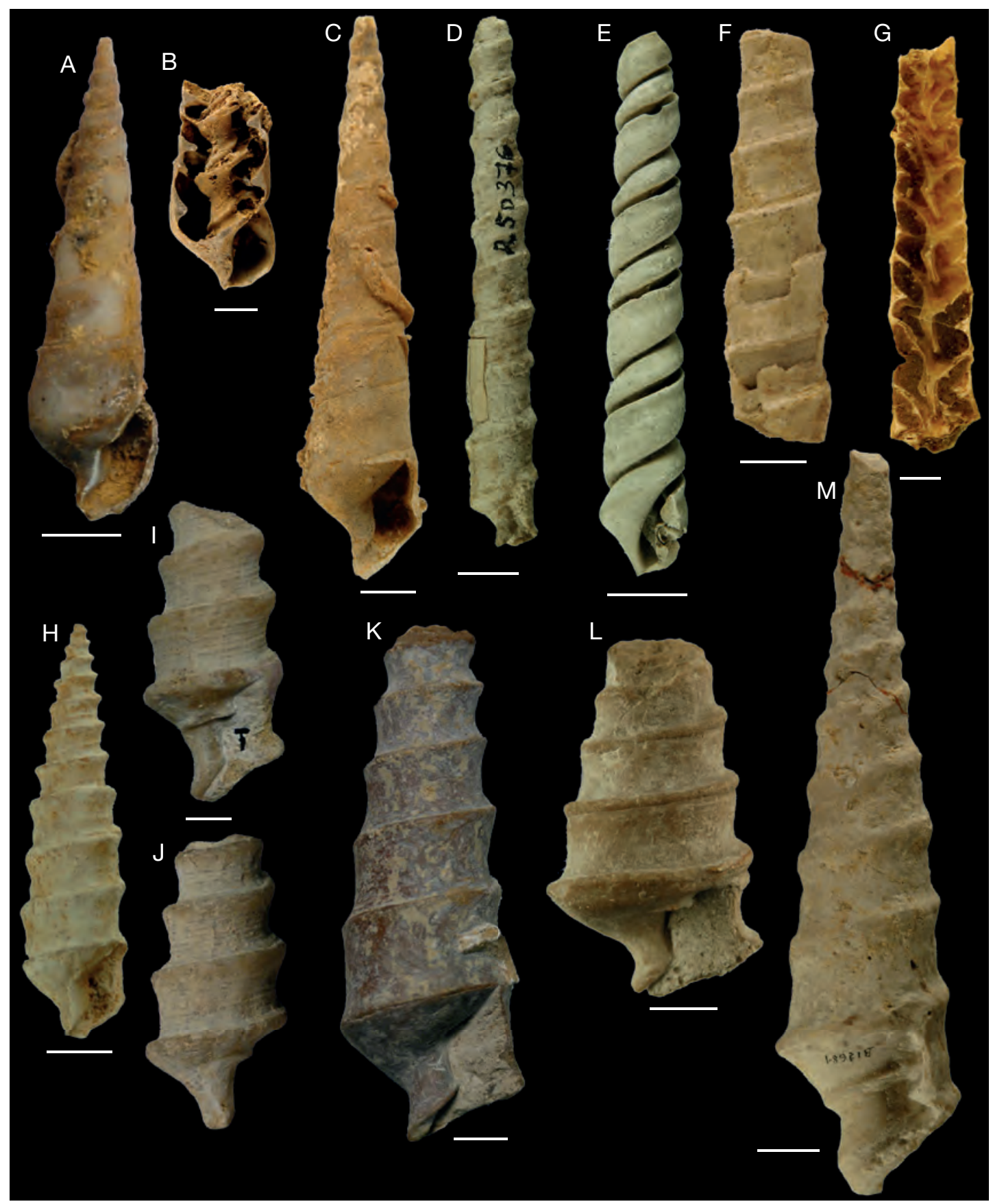

nella arduensis (Buvignier, 1852), Middle Bathonian, Martigny, La-Fosse-aux-Conains (Aisne, France), MNHN.F.R00036; I, J, Eunerinea piettei (Fischer, 1969), Bathonian, Rumigny (Ardennes, France), holotype MNHN.F.R00289; K, Eunerinea bathonica (Rigaux \& Sauvage, 1869), Bathonian, Rumigny (Ardennes, France), MNHN.F.A49003; L, Eunerinea baillei (Maire, 1913), Oxfordian, La Mouille (Haute-Saône, France), MNHN.F.A26139; M, Eunerinea defrancei (Deshayes, 1833), figure from d'Orbigny 1850, Oxfordian, Chatel-Censoir (Yonne, France), MNHN.F.B12681. Scale bars: A, E, F, 5 mm; D, 2,5 mm; B, C, G-M, 10 mm. 
Type Genus. - Cryptoplocus Pictet \& Campiche, 1861 (1861: 257).

TYPE SPECIES. — Nerinea depressa Voltz, 1836 (1836: 540 ).

Subfamily CHARACTERS. - Shells broad coniform to turriculate. Whorls moderately high, flat to strongly concave, broadly rhombic or quadrangular in cross section, columellar and basal lip describing right angle. Periphery of last whorl rounded, base moderately convex, broadly umbilicate. Umbilicus surrounded by a siphonal fasciole. One parietal plait extends diagonally into the whorl interior in Cryptoplocus Pictet \& Campiche, 1861 and the synonymous Conoplocus Pchelintsev, 1965. Wieczorek (1979) mentions an additional columellar plait in early whorls, and a columellar and a palatal plait in Trochalia Sharpe, 1850.

\section{REMARKS}

This diverse group is allocated to the Ptygmatididae because of its siphonal aureole around the umbilicus. Besides the dominant parietal plait, columellar plaits in variable numbers may occur.

\section{Family Nerinellidae Pchelintsev, 1960} (Fig. 4A-H)

Nerinellidae Pchelintsev in Pchelintsev \& Korobkov, 1960: 124.

TYPe GenUS. — Nerinella Sharpe, 1850 (1850: 107).

Type sPecies. $-N$. dupiniana d'Orbigny, 1842 (1842: 81).

FAMILY CHARACTERS. - Shells of medium size, narrow turriculate. Whorls high, moderately convex to deeply concave, with sculpture of spiral ribs or nodes. Aperture with basal siphonal notch. Columella solid, with small plait abapically. One parietal and one palatal plait. Parietal plait merging with external margin of the inductura.

\section{REMARKS}

Nerineoidea with relatively small and narrow shells and high whorls have generally been assigned to the Nerinellidae. According to Cossmann (1898), Nerinella differs from Eunerinea Cox, 1949 by its suture, which is positioned above the sutural bulge, whereas it is located on top of the bulge or between bulges in the Eunerineidae $\mathrm{n}$. fam. This distinction is unsatisfactory (see Fig. 4D). Even in the type species, Nerinella dupiniana (d'Orbigny, 1842), two weak bulges are visible (Kollmann 2005). Sharpe (1850) distinguishes Nerinella by its high, narrow whorls from Eunerinea. Although this morphological character is common to most members of Nerinella, it is not specific by itself. Most significant is the siphonal notch, a narrow sinus of the basal lip near the abapical end of the columella, which served in protruding the inhalant siphon. In contrast, the aperture of the Eunerineidae n. fam. extends into a twisted siphonal canal.

The Early Jurassic Nerinella grossouvrei Cossmann, 1896 is the earliest representative of this genus. It differs from typical Nerinellidae taxa by the obscurely angular periphery of the last whorl (Fig. 4A-C). The whorls are slightly concave to slightly convex. A columellar, a parietal and a palatal plait is present (Fig. 4B).

\section{Family EUNERINEIDAE n. fam.} (Fig. 4 I-M)

Nerineidae Zittel, 1873: 328 (pars). - Pchelintsev 1965: 20 .

Diptyxinae Bouchet \& Rocroi, 2005: 258 (non Pchelintsev, 1965 = Ceritellidae Wenz, 1940).

Type Genus. — Eunerinea Cox, 1949 (1949: 248).

TYPe SPECIES. — Nerinea castor d'Orbigny 1852 (1852: 109).

FAMILY CHARACTERS. - Shells large to very large, broad to narrow turriculate. Whorls of medium height, concave to flat. Bulges along the sutures may bear coarse tubercles.

FIG. 5. - Nerineidae: A, Nerinea clymene d'Orbigny, 1850, figure from d'Orbigny 1851, Oxfordian, Châtel-Censoir (Yonne, France) MNHN.F.B12369; B, Nerinea mosae Deshayes, 1827, axial section, Oxfordian, Châtel-Censoir (Yonne, France), MNHN.F.R09444; C, Nerinea mosae, small specimen with almost complete aperture, Kimmeridgian, La Combe de Vaux (Ain, France), MNHN.F.A49004; D, Italoptygmatis digitalis Stoliczka in Stur, 1863, Cenomanian, Cherghes (Romania), NHMW 2013/0264/0001; E, F, Parasimploptyxis subturbinata (Pchelintsev, 1953), external view and axial section, Late Cretaceous, Goygol (Azerbaijan), NHMW 1847/XIII/22; G, Simploptyxis digitalis (Stoliczka, 1863), axial section, Cenomanian, Cherghes (Romania), NHMW 1853/III/30; H, Parasimploptyxis pailletteana (d'Orbigny, 1842), Turonian, Gams bei Hieflau (Austria), NHMW 2013/0051/0001; I, Simploptyxis ampla (Münster, 1844), axial section, Turonian, Gams bei Hieflau (Austria), NHMW 2002/0050/000; J, Plesioptygmatis sp., Late Middle Maastrichtian, Sabana 


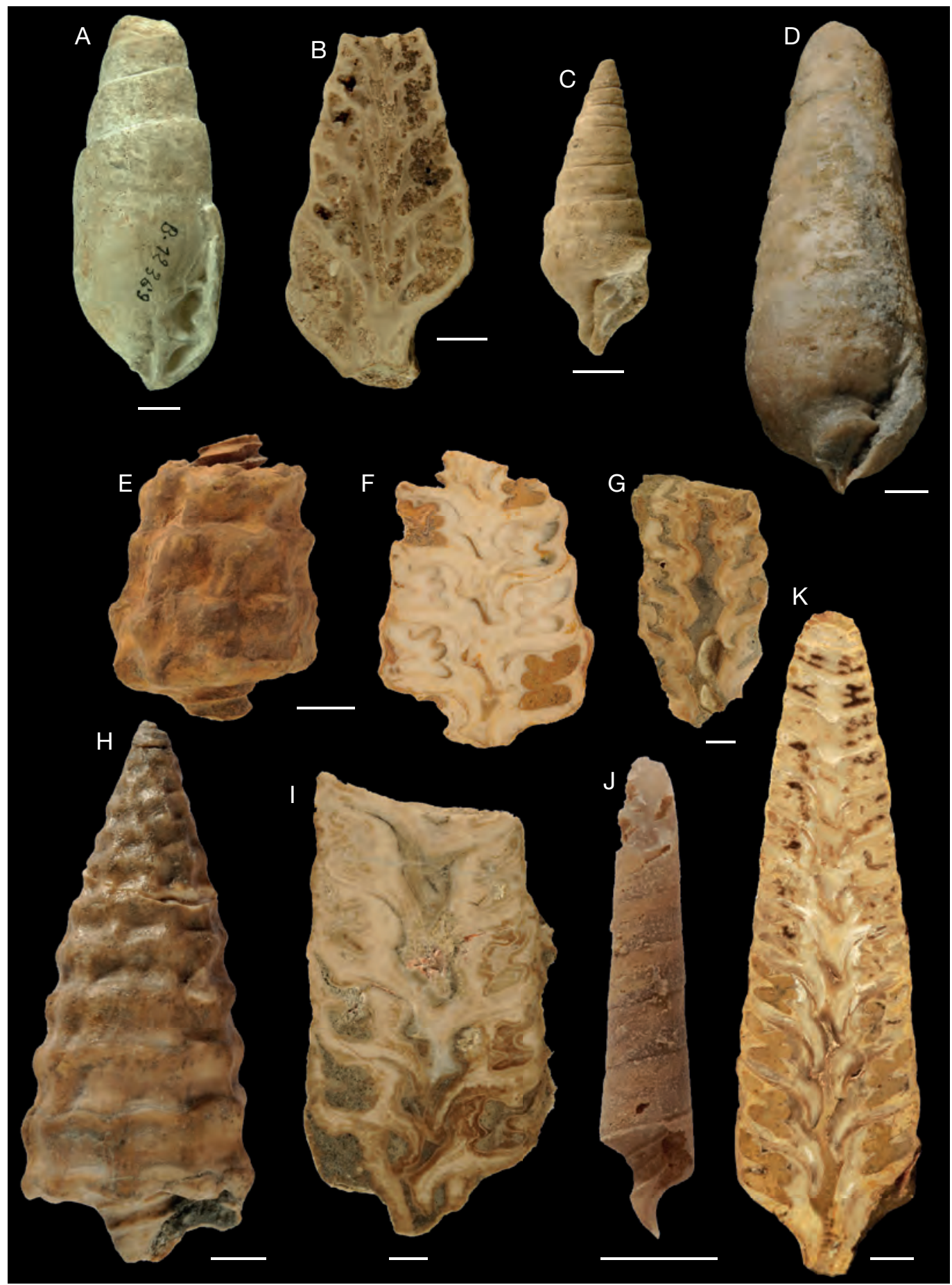

Grande Quadrangle (Puerto Rico), NHMW 20130267/000; K, Simploptyxis nobilis (Münster, 1844), Late Santonian, Dreistätten (Austria), NHMW1853/III/30. Scale bars: $10 \mathrm{~mm}$. 
Whorl periphery explicitly angular, base rather low. Aperture rhombic in outline, with narrow, twisted siphonal canal. Columella generally solid with large abapical plait delimiting siphonal canal and occasionally a small one adapically. Parietal plait prominent inside shell, decreasing in strength towards aperture and merging with external margin of the inductura. Palatal plait decreasing in size towards aperture.

\section{REMARKS}

The internal plaits are largest before the penultimate whorl (Wieczorek 1979; Barker 1990). In the aperture, the columellar plait delimits the siphonal canal against a thick inductura (Figs 4I, J; 7A). The parietal plait flattens towards the aperture and circumscribes the inductura (Fig. 7A). Equally, the palatal plait disappears almost completely towards the margin of the labrum (Wieczorek 1979). In Neoptyxis Pchelintsev, 1934 an additional small plait is developed in the adapical portion of the columella.

\section{THE NEW FAMILY NAME EUNERINEIDAE N. FAM.} Cox (1949) underlines that the genus Nerinea as conceived by d'Orbigny (1842), Zittel (1873), Cossmann (1896), Dietrich (1925), Wenz (1940) and consequently all other researchers - cannot be upheld for three reasons:

1) following d'Orbigny (1842), all monographs refer to Nerinea tuberculosa Defrance, 1825 as type species. Originally, Defrance had characterized a specimen as "Neriné tuberculeuse". This vernacular name was latinized to Nerinea tuberculosa Defrance, which therefore is invalid from a nomenclatural standpoint; 2) the genus Nerinea was formally established by Deshayes (1827) upon Nerinea mosae Deshayes, 1827. Cossmann (1898) assigned this species to Ptygmatis Sharpe, 1850 but it actually belongs to the genus Phaneroptyxis Cossmann, 1896, which therefore is synonymous with Nerinea. Cox (1949) therefore renamed Nerinea, as it was commonly used, into Eunerinea with Nerinea castor d'Orbigny, 1850 as type species.

3) Bouchet \& Rocroi (2005) replaced the family name by Diptyxidae Pchelintsev, 1965. Diptyxis Oppenheim, 1889 belongs to the Ceritellidae (see above) and cannot typify the present family. It is therefore renamed into Eunerineidae n. fam. with Eunerinea Cox, 1947 as type genus.

\section{Family NERINEIDAE Zittel, 1873 (pars) \\ (Fig. 5A-K)}

Phaneroptyxidae Pchelintsev, 1965: 126.

Type Genus. - Nerinea Deshayes, 1827 (1827: 535).

TYPE SPECIES. — Nerinea mosae Deshayes, 1821 (1821: 535).

FAMILY CHARACTERS. - Shells of this variable group of medium size to very large, high oviform to broad turriculate, broadly umbilicate to anomphalous. Whorls high, cylindrical to convex, smooth to strongly sculptured. Last whorl high, periphery evenly rounded to bluntly angular. Prominent siphonal fasciole, bent outwards. Aperture narrow, abapical of 1-3 collumellar plaits extending into aperture and delimiting siphonal notch (siphonal plait). 1 parietal and 1 palatal plait hardly elevated in aperture.

\section{REMARKS}

Figure 5 illustrates the high diversity of this family. Cossmann (1896) allocated members of this family to Ptygmatis but they differ by their siphonal canal. Cossmann $(1896,1898)$ positioned Phaneroptyxis (recte Nerinea) within the Itieriidae. Both possess a siphonal fasciole. In the Itieriidae the whorls are narrow and embrace the preceding ones almost completely.

Family ITIERIIDAe Cossmann, 1896

(Fig. 6A-F)

Itieriidae Cossmann, 1896: 16.

TYPE GENUS. — Itieria Matheron, 1842 (1842: 493).

TyPe SPECIES. - Itieria cabanetiana d'Orbigny, 1841 (1841: 318).

FAMILY CHARACTERS. - Shell oval to coniform, with high, narrow whorls. Spire short, irregularily coiled, depressed or convolute. Base umbilicate, with siphonal fasciole or short siphonal canal. Columella low, with one plait in Jurassic taxa, up to three in Cretaceous ones. Palatal wall with broad but low plait or pouch.

\section{REMARKS}

The whorls are high and narrow in cross section and reminiscent of the Acteonelloidea but possess a central cavity and a siphonal fasciole. In some cases only the internal mould of the cenrtral cavity is preserved (Fig. 6C). The Early Cretaceous Eotrochactaeon Akopjan, 1976 possesses a broad oviform 


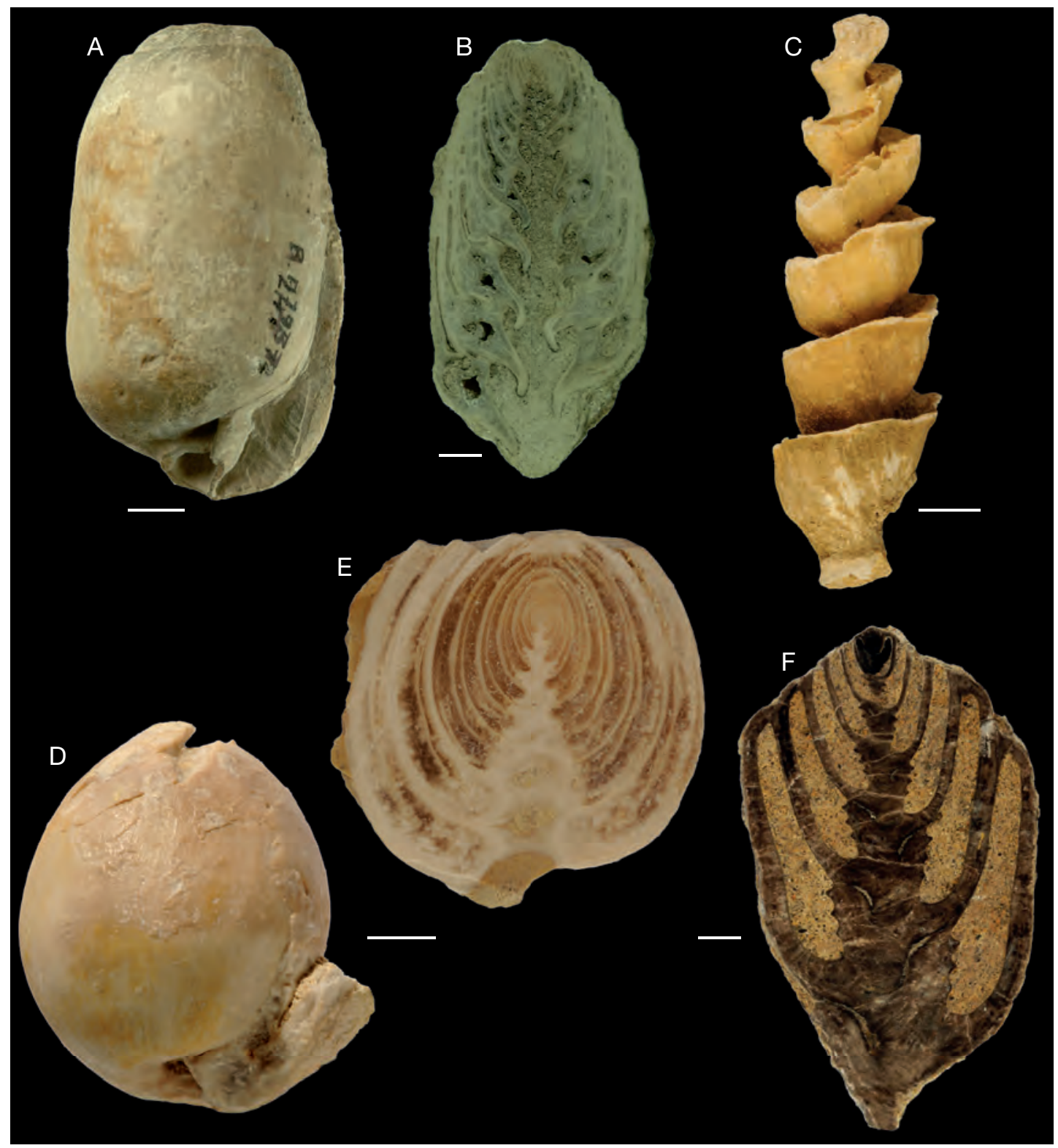

FIG. 6. - Itieriidae: A, Itieria cabanetiana (d'Orbigny, 1841), Lower Kimmeridgian, Oyonnax (Ain, France), paralectotype MNHN.F.A24437; B, Itieria cabanetiana, axial section, Lower Kimmeridgian, Nantua (Ain, France), MNHN.F.B11796; C, Itieria globosa Favre, 1913, mould of the central cavity of the columella, Tithonian, Dörfles, Ernstbrunn, Austria, NHMW 2013/0271/0001; D, E, Peruviella dolia (Roemer, 1849), Albian, Canapebe (Brazil), NHMW 2013/0050/0002; axial section, same locality, NHMW 2013/0050/0003; F, Eotrochactaeon zumoffeni (Delpey, 1939), figure from Kollmann 1982, Lower Aptian, Levadia (Greece), NHMW 1884/21/69. Scale bars: 10 mm.

shell with a short spire and 3 columellar plaits and is externally homologous with the Acteonelloidea genus Trochactaeon Meek, 1863 (Fig. 6F). A siphonal fasciole recognizable in axial sections of the columella distinguishes Eotrochactaeon from this genus (see Kollmann 1982; Sohl \& Kollmann 1985). 


\section{FUNCTIONAL MORPHOLOGY OF THE NERINEOIDEA SHELL}

\section{CRITICAL REVIEW OF PREVIOUS INTERPRETATIONS}

Besides the large size of some taxa, the internal plaits are the most striking morphological features of the Nerineoidea. Their existence has stimulated various interpretations which are reviewed briefly:

\section{Squeezing theory}

Following Dall (1894), Dietrich (1925) has interpreted the formation of plaits by the squeezing of an outgrowing mantle into the shell, especially by a tight columellar muscle. This interpretation presumes that a more or less random process would have resulted in genetically reproduced structures. According to Signor \& Kat (1984), the weakness of this theory lies in the fact that the plaits are regular and partly positioned on the columella where no mantle is attached.

\section{Growth regulation}

Dacqué (1921) considers the plaits as a regulative against excessive growth. They are supposed "to be an adaption to reduce the total size, respective length, a preventive measure against an exaggerated turritellid type". This theory is rooted deeply in the Lamarckian tradition. The fact that there is no random arrangement of plaits indicates that they had definite functions.

\section{Attachment of internal organs}

Besides a possible support for respiratory structures, Vaughan (1988) considers a general strengthening or buoyancy stabilising role as most likely. Vaughan's proposition that respiratory organs were attached to the plaits could only apply to the parietal and palatal portions but not to the columella, which supported the columellar muscle.

\section{Reduction of space}

According to Waite et al. (2008), the last whorl may have provided the necessary space for the interior organs but plaits may have served to fill excess empty space in earlier whorls. The larger the animal the more space had to be filled. The plaits would therefore lack any function in the anatomy of the snails, which seems unlikely.

\section{Increased sturdiness}

Peron (1901) has considered the internal plaits as devices to strengthen the shell against mechanical destruction. This can be ruled out. The outer lip was delicate because of the subsutural notch and was hardly supported by the palatal plait, which is only weakly or even not developed in this position (Barker 1990).

\section{Protection against predators}

Signor \& Kat (1984), suggest that all plaits besides the columellar plaits provided protection against shell-peeling crabs such as the Callapidae. Crabs start shell-peeling at the outer lip and proceed against the coiling direction (Schäfer 1962, Ishikawa et al. 2004). Ishikawa et al. (2004) have stated a higher survival rate of turriform gastropods because of the ability of the animal to withdraw deeply into the shell. This cannot apply to the Nerineoidea because of the narrow interior of the whorls, which did not permit a further withdrawal. The protection against durophagous crabs and shell drilling postulated by Vermej (1977) and Barker (1990) can be ruled out for two reasons: The reduced size of the plait on the labrum and because durophagy among crabs has not been recorded before the Maastrichtian (Dietl \& Vega 2008), when the decline of the Nerineoidea was in its final stage.

\section{NEW INTERPRETATION}

In the above-quoted interpretations the internal plaits have been treated undifferentiatedly as serving a single purpose. As in extant gastropods, the columellar muscle was attached to the columella and moulded its surface. It is therefore evident that the columellar plaits have to be distinguished from other plaits by their function.

\section{Columellar plaits and locomotion}

According to Signor \& Kat (1984), grooves between the plaits are occupied by strands of the columellar muscle. The grooves and not the plaits are therefore functionally relevant. The columellar muscle is attached at variable distances from the aperture to the columella (up to $4 \frac{1}{2}$ whorls in Terebra species). When the muscle is expanded, the grooves direct the strands on the shortest path and allow a differentiated movement of the pedal mass (Signor \& Kat 1984). 


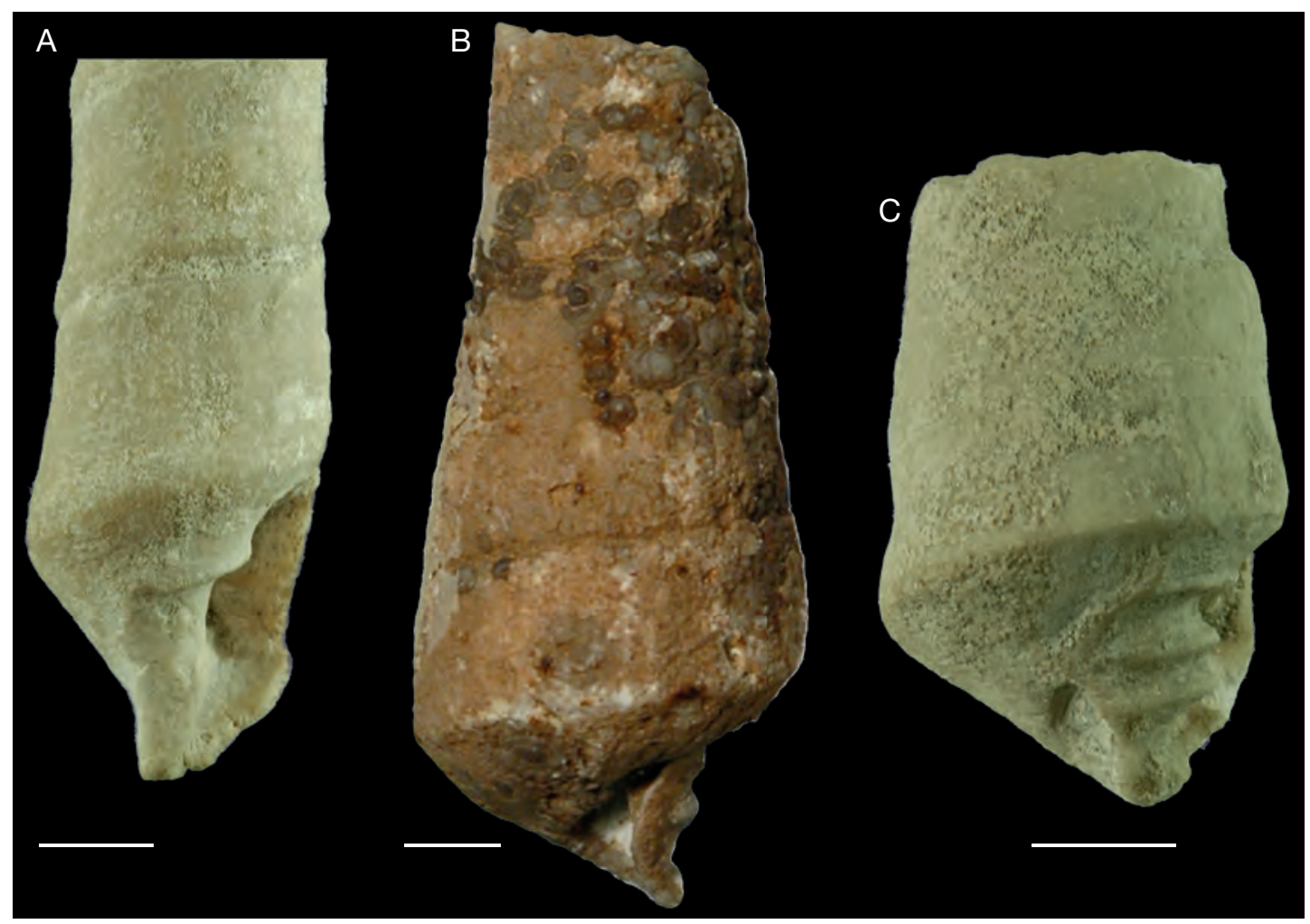

FIG. 7. - Apertures of Eunerineidae n. fam. and Ptygmatididae: A, Eunerinea bernardiana (d'Orbigny, 1850), Kimmeridgian, La Combe de Vaux (Ain, France), MNHN.F.A49010, the abapical columellar plait delimits the siphonal canal and the parietal plait merges into the external margin of the inductura; B, Ptygmatis bruntrutana (Thurmann, 1832), Middle Oxfordian, Wagnon (Ardennes, France), MNHN.F.B12823, the inner lip is detached, two plaits extend to its external margin; C, Ptygmatis gradata (d'Orbigny, 1852), Kimmeridgian, La Combe de Vaux (Ain, France), MNHN.F.A49005, the parietal plait merges with the margin of the columellar lip; the two columellar plaits extend to the exterior margin of the columellar lip. Scale bars: $5 \mathrm{~mm}$.

In Caenogastropoda, the function of columellar plaits is to enlarge the lateral space for muscle attachment (Price 2003). The contraction of the columellar muscle is mainly performed by fibres oblique to its longitudinal extension (Thompson et al. 1998). These plaits, which are rather flat and rounded on top, support the movement of the head-foot mass in and out of the shell. In contrast to this function, the grooves between the strongly accentuated plaits of the Nerineoidea serve the burrowing in unconsolidated sediments (Signor \& Kat 1984). Fretter \& Graham (1954) have demonstrated the strong positive correlation between burrowing and columellar plaits in Acteon tornatilis (L.), and Mikkelsen (2002) has done the same in various other taxa of Heterobranchia.
In these taxa, head lobes formed by expanded and flattened cephalic and labial tentacles are adapted for ploughing through soft sediments.

It is therefore evident that the columellar plaits and grooves were primarily functionally related to life in soft-bottom environments. Because of the large shell size, the muscle strands must have been quite powerful and left deep grooves on the columella. The abapical columellar plait had a dual function: On one hand it served as a siphonal plait by directing the water current entering the mantle cavity through the inhalant canal or notch, as is frequently the case in extant gastropods. On the other hand, it delimited the columellar lip abapically and, with it, the space occupied by the columellar muscle (Fig. 7A-C). 

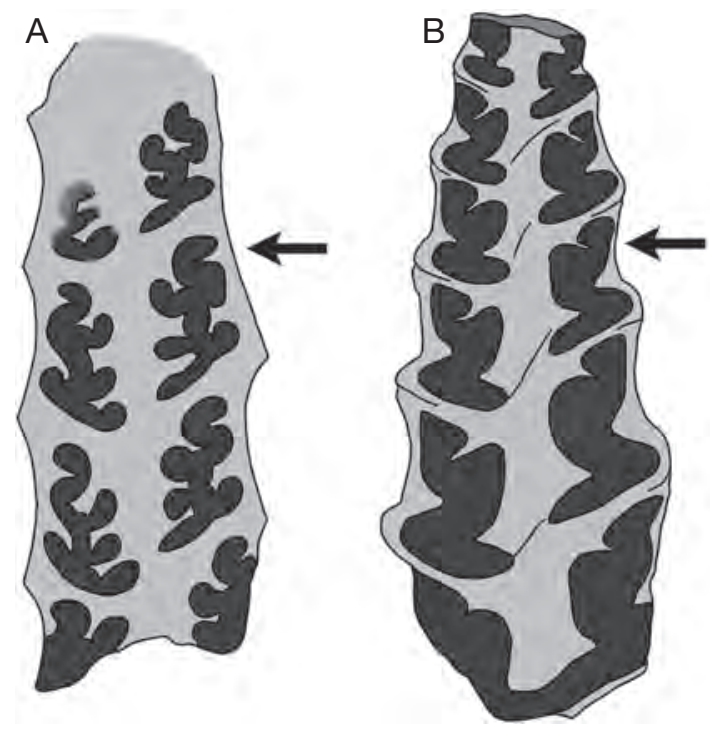

FIG. 8. - Axial sections through Nerineoidea Zittel, 1873 shells: A, Ptygmatididae Pchelintsev, 1960; B, Nerineidae Zittel, 1873. Arrows indicate the tube-like space delimited by internal plaits and interpreted as equivalent to the posterior pallial chamber (figures modified after Delpey 1940).

The morphology of the columella in the Ceritellidae, Nerinellidae and Eunerineidae n. fam. does not provide evidence for a subdivided columellar muscle. The two collumellar plaits of the Ptygmatididae and the Nerineidae indicate a subdivision into two strands. The angles of the grooves towards the shell axis vary slightly. This would have allowed portions of the foot to move independently ( $\mathrm{Si}$ gnor \& Kat 1984). In Ptygmatis the subdivision of the columella and consequently of the columellar muscle persisted to the inductura. This is illustrated by Ptygmatis bruntrutana (Thurmann, 1832), in which the plaits extend to the undetached margin of the columellar lip (Fig. 7B).

Turritelliform snails are shell draggers. The action of the foot is supported by the columellar muscle (Signor \& Kat 1984). The extent of contraction is proportional to the length of the muscle. A long muscle is therefore advantageous for this kind of locomotion. Similar to extant high turriculate gastropods, the muscle of the Nerineoidea must have been coiled several times around the columella. The muscle attachment leaves no scars, but the animal could not retract deeper than the point of attachment closest to the aperture (Price 2003). In the Nerineoidea this was probably at the point of full plait development, which is approximately $1 \frac{1 / 2}{2}$ volutions prior to the aperture. The decrease of the plaits towards the aperture indicates an increasing lateral mobility of the muscle strands towards the head-foot mass.

\section{Palatal and parietal plaits, subsutural notch}

The palatal and parietal plaits were formed by protrusions of the mantle. Because of its delicacy, no muscles could have been attached to the parietal plait. The palatal plait is broad but its dorsal position in the living animal excludes muscle attachment for anatomical reasons. Like the columellar plaits, these plaits reached their full size approximately $1 \frac{1 / 2}{2}$ volutions prior to the aperture. Except for the Pseudonerineidae and Ceritellidae, the parietal and the palatal plait delimit a space in the posterior part of the whorls, which opens towards the anterior space of the whorls in a narrow slit (Fig. 8). This space is interpreted as an equivalent to the pallial caecum or posterior chamber of Heterobranchia, which runs dorsally of the mantly cavity or anterior chamber and along the visceral hump towards the apex. Brace (1977) describes it as "a respiratory innovation to offset functional inefficiencies which might otherwise have been incurred upon the increase in size...". Mikkelsen (2002) assumes that the development of ciliated strips in the mantle cavity was associated with a reduction or total absence of the gills, which is the case in many Heterobranchia (Jensen 1996).

According to the space circumscribed by the parietal and palatal plaits, the posterior chamber would have been relatively large in the Nerineoidea. The Nerineoidea are, however, several orders of magnitude larger than all extant Heterobranchia but their whorl cross section is rather small compared with the overall size. There was clearly no space for gills of adequate size in the final whorl. Accordingly, only the elongated posterior cavity could have provided the necessary respiratory surface. The fact that plaits are lacking, vary in size in the different taxa, or that only one of each kind is developed was probably due to the different grade of calcification within the mantle folds. 
The subsutural notch opened just below the suture. It is narrow at its end and therefore no sutural ramp is developed. Located between the parietal and the palatal plait, it occupied a right-dorsal position in the animal. This position agrees with the exhalant opening in the adapical part of the aperture of extant Heterobranchia. Through this opening, body waste from the pallial cavity and the posterior cavity is expelled by ciliary movement (Fretter \& Graham 1954; Morton 1972; Brace 1977; Kay et al. 1998; Mikkelsen 2002).

According to Sälgeback \& Savazzi (2006), a narrow exhalant opening is restricted to taxa whose anus is located in the back of the anterior pallial chamber from where waste is expelled by ciliary action. In contrast, a broad notch and sutural ramp is coupled with an anus positioned at the end of a rectum which expels waste material directly into the surrounding water. This is, for example, the case in Akera bullata Müller (see Morton 1972; Brace 1977) and is assumed for the extinct Acteonelloidea (Kollmann 1967; Sohl \& Kollmann 1985). The position of the notch indicates a rectum position in an almost dorsal position of the pallial cavity, which opened towards right.

The inferred courses of water currents in the interior cavities of the Nerineoidea are shown in Fig. 9. When the water current passed the pallial cavity, it was divided in two branches: One sweeps away the waste from the anterior pallial cavity, the other one is swept by ciliary movements into the posterior cavity, where oxygen is extracted and waste is removed through the subsutural notch.

\section{The Ptygmatidinae, a special case?}

The axial sections of Fig. 3 show the extreme narrowing of the whorl cross section preceding the final $1 \frac{1}{2}$ whorls in Ptygmatis and related forms; this left hardly any space for the visceral hump (Wieczorek 1979; Barker 1990). From this space reduction, Waite et al. (2008) have deduced a total sealing of early whorls. This has to be excluded for the following reason: The additional aragonite which topped the plaits must have been deposited at the interface between shell and mantle. Therefore, the mantle must have been fully functional and could not have been isolated in this part of the shell. The

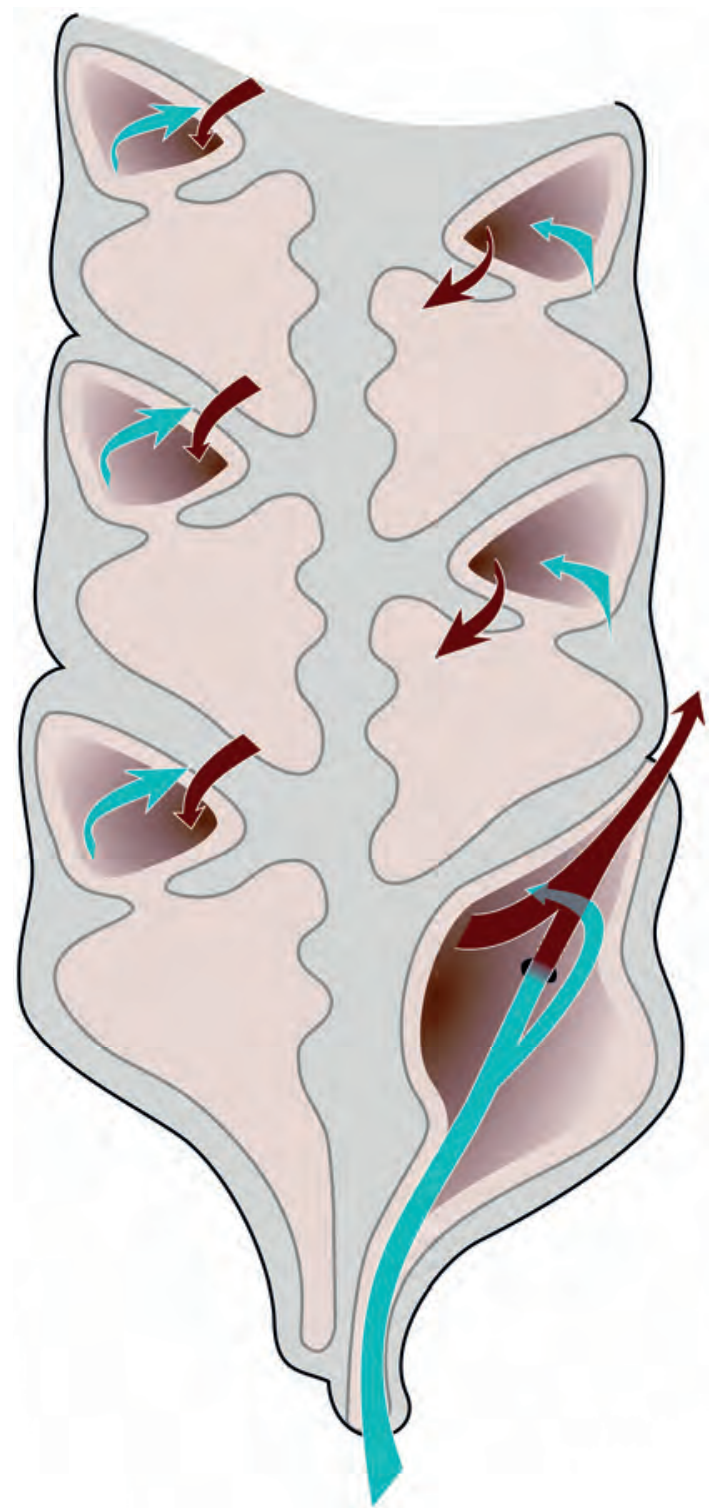

FIG. 9. - Water currents in the pallial cavities of Eunerinea. After entering the anterior pallial cavity, the water current induced by ciliary movement (blue) splits into two branches: one passes the anus and other excretion organs (indicated by a black spot) and carries the waste (red) to the subsutural notch where it is expelled. The other branch is directed into the posterior cavity. The counter current (red) sweeps water depleted of oxygen along the posterior (palatal) plait to the subsutural notch.

enlargement and bifurcation of plaits has clearly multiplied the respiratory surface. There is a rather small posterior chamber; it is subdivided by a small 
palatal plait, which may have separated the inhalant from the exhalant stream (Figs 3F; 8A).

It is, however, unlikely that the respiratory organ was so much larger in Ptygmatis than in other Nerineoidea which just show only two simple plaits. More reasonably, Ptygmatis provides insight into the extent to which the mantle has generally been folded to enlarge the respiratory surface. In contrast to Ptygmatis, most of the folds may not have been moulded by the aragonite layers deposited at the interface between mantle and shell in other Nerineoidea.

\section{The rod system}

It was discovered by Barker (1990) in sectioned shells of most Nerineoidea taxa and interpreted as a duct system of the gland/gonad complex. This system has no equivalent among extant taxa (Voltzow 1994). It may have played an important role in supporting the respiratory surface. As visible in Figure 3I, the tubes in Ptygmatis bruntrutana (Sharpe, 1850) were positioned between the plaits and attached to the shell by small protrusions. The rigidity of the rods is evident from their fossil preservation. Therefore, they must have been restricted to organs which were more or less stable during the snail's activities. In a respiration chamber the rods could have maintained the stability of soft tissue not supported by the visceral hump. Alternatively, they may have had some duct function. Barker (1990) pointed out three possibilities: the absorption of food, the production of gametes and a storage function. In the respiration chambers the ducts could have been parts of the vascular system, although this was excluded by Barker based on their softness in extant gastropods.

Barker (1990) found no duct system in the Nerineidae. The whorl sections are much more voluminous in this family than in the Nerinellidea and the Ptygmatididae. There was much more space for a pallial sac even in early whorls, which would have made a support of soft tissue superfluous.

\section{Could the head-foot mass be retracted?}

The extreme narrowing of the whorls prior to the final ones by internal plaits did not leave much space for the visceral mass. The plaits disappear either totally or decrease in size in the final $1 \frac{1}{2}$ whorls (Wieczorek 1979; Barker 1990). The internal space is therefore considerably larger in the final volution than in the preceding ones but still rather limited in cross section compared to the size of the shell. As stated above, the depth of the sutural notch suggests a rather shallow pallial cavity.

Consequently, the visceral mass must have inhabited a large part the final whorls. Space for the retraction of the head-foot mass must have been very restricted or non-existent. The morphology of the columellar lip provides an estimate on the degree of retraction (see above). In groups with smooth columellar lips the guiding function of the muscle strands was restricted to the shell interior, indicating at least a partial withdrawal of the head- foot mass. This is the case in Eunerinea. In contrast, the plaits in Ptygmatis extend to the external margin of the columellar lip (Fig. 7B, C). This indicates a leading function even at the aperture and makes sense when the animal could not withdraw into the shell.

\section{MODE OF LIFE AND DISTRIBUTION}

\section{ANIMAL-SEDIMENT INTERACTION}

\section{AND TAPHONOMY}

The large shell size in many taxa and thus the heavy weight, the comparatively small aperture, the inferred muscle strands and an apertural plane almost parallel to the shell axis exclude rock-clinging for the Nerineoidea. The turriculate shell and the occurrence in originally unconsolidated sediments indicate a motion by shell-dragging as in Turritella (Allmon1988).

This is supported by the inferred foot. According to McNair et al. (1981), a low length/width ratio of apertures, as in the Nerineoidea, is indicative for shell draggers with a "short and stubby foot squarish to slightly elongate in shape". Campanile symbolicum Irredale is comparable: its small foot size is compensated by its higher mobility (Houbrick 1981). Following McNair et al. (1981), the inferred sole of the Nerineoidea was too small for creeping on the surface of soft sediments. These gastropods probably ploughed through the soft sediments with their foot shallowly buried. Houbrick (1991) has 


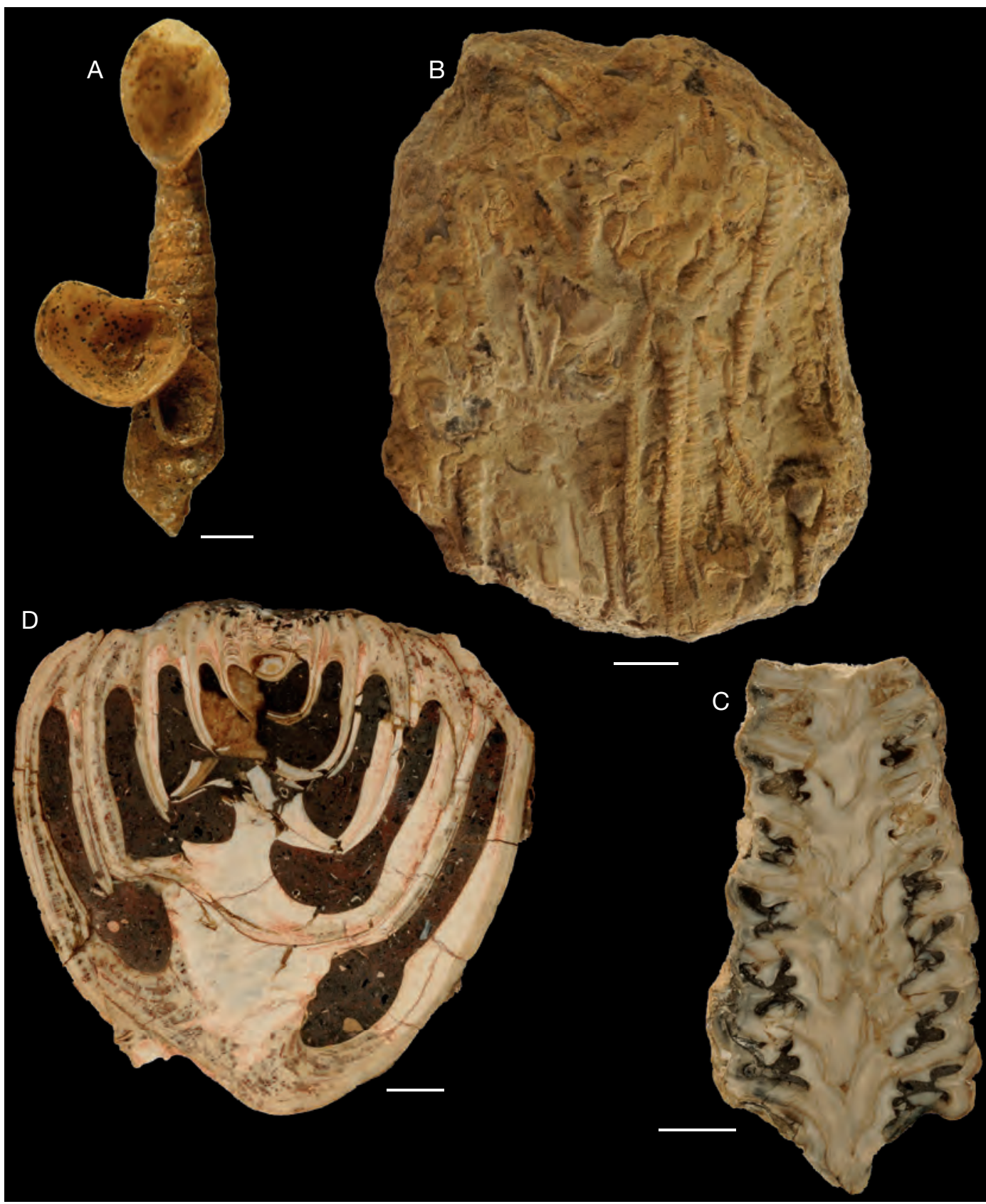

FIG. 10. - Taphonomy (Nerineoidea and Acteonelloidea): A, Nerinella grossouvrei Cossmann, 1896 with epibiontic bivalves; MNHN.F.A51318; B, Nerinella flexuosa (Sowerby, 1831), Gosau (Austria), Late Cretaceous, NHMW 2013/0268/000; the shells are aligned by a moderate water current; C, Parasimploptyxis buchi (Münster, 1829), Late Cretaceous, Abtenau (Austria), NHMW 2002z0074; following the breakage soft mud entered the shell synchronous with the decay of soft tissue; fragments of the shell were therefore kept in their original position; D, Trochactaeon ventricosus Hojnos, 1921, Campanian, Hieflau (Austria), NHMW 2013/0052/0001; shell material sealed the adapical portions of the whorls which were most endangered by abrasion; mud entered the shell synchronously with the decay of soft parts. Scale bars: $10 \mathrm{~mm}$. 
described this in Telescopium: due to their heavier weight, large specimens are covered half by sediment, but small ones plough with the dorsal regions of the shell horizontal at a level with the surrounding sediment. Variable parts of the shell are therefore covered by sediment. The muscle strands are effective devices for ploughing through unsolidified sediments and have enabled gastropods to enter also higher energetic environments.

It has been discussed in the literature if the Nerineoidea lived epifaunally or infaunally. Barker (1990) pointed out a positive correlation between high-spired shells and an infaunal life in gastropods. Opposite to this interpretation, Delpey (1937), Wieczorek (1979), Tiedt (1958), Dauwalder \& Remane (1979) and Waite et al. (2008) deduced an epifaunal mode of life for the Nerineoidea based on epibionts on the shell surface (see Fig. 10A). A coiled Spaerulites shell around a Nerinellidae specimen in its growth direction caused Vogel (1968) to come to the same conclusion.

Both erosion (see Wieczorek 1979) and breakages indicate that shells were displaced and uncovered from sediment. As no obvious commensalisms existed between the gastropods and their epibionts, a settlement on the shell surface during lifetime cannot be proved. It seems much more likely that epibionts settled post-mortem on shells freed from the sediment after the soft parts had decayed (Fig. 10A). This is evident from the settling of epibionts even within the aperture (Wieczorek 1979).

The shallow siphonal notch and lack of plaits in the Pseudonerineidae suggest only a moderate subsidence of the animal into the sediment (Vermej 1987). This differs from the other Nerineoidea families: Comparable to extant cerithiiform gastropods (see: Sälgeback \& Savazzi 2006), the twisted rostrum of the Nerinellidae taxa provided an additional elevation of the opening of the siphonal canal. In the Ptygmatididae the siphonal notch was located on a siphonal fasciole, which served the same function.

Adapical sinuses occur in taxa of different systematic position: in the Cerithioidea families Batillariidae Thiele, 1929 and Thiaridae Gill, 1871 (after Sälgeback \& Savazzi 2006), in Campanile symbolicum Iredale, 1917 (after Houbrick 1984), in the Streptacididae and in various Architectibranchia
(Gründel \& Nützel 2012). This structure serves to discharge body waste well away from the inhalant current and "allows the exhalant current to flow unimpeded when the outer lip lies on the surface of the sediment" (Sälgeback \& Savazzi 2006). It is therefore lacking in effective burrowers but is characteristic for gastropods of semi-infaunal habit.

\section{ECOLOGY}

The Nerineoidea are restricted to shallow marine subtidal siliciclastic and carbonate platform environments (Tiedt 1958; Herm 1977; Wieczorek 1979; Sirna 1995; Kowalke \& Bandel 1996; Kollmann et al. 2002). Within this frame, individual families inhabited different ecological niches (Fischer 1969; Wieczorek 1979; Sirna \& Mastroianni 1993; Sirna 1995; Kollmann et al. 2002).

As expected, taxa with columellar plaits tolerated more agitated environments because of their powerful muscle strands than those without them. Sedimentological data indicate that the Ptygmatididae and the Eunerineidae n. fam. are restricted to shallow, moderately agitated environments (Shikama \& Yui 1973; Wieczorek 1979; Kollmann et al. 2002) but tolerated occasional higher energy events (Sirna \& Mastroianni 1993). Herm (1977) recorded large Nerineidae from deposits of unprotected lagoons in the Late Cretaceous Gosau Group of the Northern Calcareous Alps. The shells are commonly abraded and fragmented and were clearly transported within the environment (Wieczorek 1979). The Pseudonerineidae, which lack internal plaits and the Ceritellidae inhabited low-energy environments (Wieczorek 1975, 1979). Pseudonerinea has been recorded from shallow lagoonal environments in the late Early Cretaceous Fredericksburg Group of West Texas (Kollmann et al. 2002).

Oriented assemblages of shells were deposited by moderate water currents (Fig. 10B). In contrast, mass occurrences - which are among the most spectacular fossil invertebrate lagerstaetten - are generally chaotic assemblages of shells. Due to the habitats of the Nerineoidea above the storm wave base, water agitation could produce sufficient energy to displace them within their environments (Wieczorek 1979; Waite et al. 2008). Kouyoumontzakis (1987), Saul \& Squires (1998) and Cotaldo (2013) 


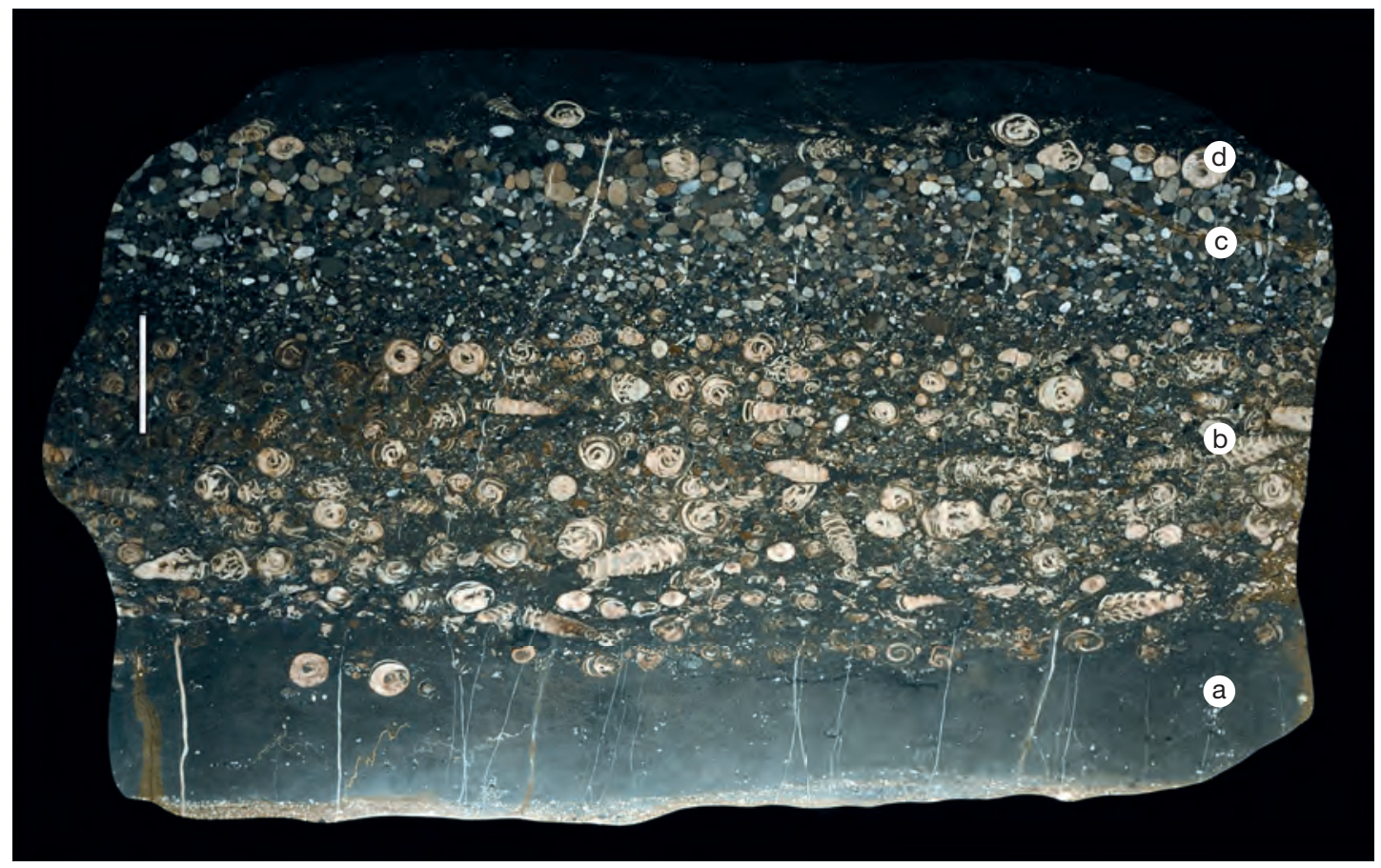

FIG. 11. - Mass occurrence of the Nerineidae species Simploptyxis nobilis (Muenster, 1844), Late Cretaceous, Gosau, (Austria), NHMW 2013/0270/00; the sequence represents a high energy event: layer a, bioturbated silty sand. Isolated specimens may represent the actual abundance; layer $\mathbf{b}$, chaotic accumulation of generally broken shells dislocated more or less in situ; layer c, introduction of well-rounded pebbles coarsening upwards; in layer $\mathbf{d}$, which is only represented by a few millimetres, the original environment was re-established. Scale bar: $100 \mathrm{~mm}$.

demonstrated that the predominant substratum of mass occurrences is grainstone in which the smaller particles have been removed by winnowing.

Figure 11 shows a section through a mass occurrence of the Nerineidae genus Simploptyxis Tiedt, 1958 from the Late Cretaceous of the Eastern Alps. The basal bioturbated sand contains only a few Simploptyxis, which may represent the actual abundance in this environment (Fig. 11 [layer a]). It is overlain by a layer of densely packed shells of the same generic composition (Fig. 11 [layer b]). The strong reduction of substrate indicates an accumulation by winnowing. Following the accumulation of the gastropods, pebbles coarsening upwards were deposited (Fig. 11[layer c]). Finally, the original environment was re-established and silty sand was deposited again but is preserved only in small remains on this isolated rock slab (Fig. 11 [layer d]).
This sequence indicates a high-energy event. The winnowing of the sediment is followed by the input of pebbles from near-shore environments. Almost all shells are broken but the fragments are only moderately dislocated. This indicates that the mantle kept the broken parts more or less in their original position after the shells were buried. When the soft parts decayed, they were successively replaced by sediment, which has preserved this situation (see also Fig. 10C).

\section{DIETS AND FEEDING}

Because of occurrences near fossil reefs, Peron (1901) concluded that the Nerinellidae fed on corals ..."dont ils se nourissaient sans doute." Details about the occurrence Peron had in mind are not known, but previous chapters discussed that Nerineoidea inhabited exclusively unconsolidated sediments. 
The diets of Heterobranchia are very diverse and the group comprises both carnivorous taxa mostly feeding on polychaetes and herbivorous taxa (see the compilation in Göbbeler \& Klussmann-Kolb, 2001). Considering the restricted mobility discussed above, active hunting can be excluded. Filter feeding or deposit feeding, which both require no or little movement, would be possible modes of food intake. Because of the high abundance, Saul \& Squires (2002) suggested filter feeding. This would require an inhalant depression in the substratum as in Turritella communis Risso, 1826 (Yonge 1946). The relatively high rate of sediment transport in the living environment of the Nerineoidea might rule this feeding mode out. Taylor et al. (1980), Barker (1990) and Fischer (1969) supposed deposit feeding in this group ("microphagous or detritiphagous food intake" according to Fischer). This is supported by the substratum grain sizes (see above).

According to Wieczorek (1979), the abundance of shells per square meter varies between some tens and several hundred. From the "Main Nerineoid Limestone" of the Jura Mountains, Dauwalder \& Remane (1979) and Waite et al. (2008) have calculated an abundance of 7000 specimens of Eunerinea by $\mathrm{m}^{3}$. They are oriented mostly parallel or moderately oblique to the bedding plane. Waite et al. (2008) consider this high abundance as an almost exact image of the Nerineoidea population and explain it by a high nutrient input from continental areas. Although calculated on a three-dimensional base, this density compares with the number of the extant herbivorous Haminoea orbignyana Férrusac, 1822 in an estuarine coastal lagoon of Portugal, for which Malaquias \& Sprung (2005) calculated a mean population density of $341 \mathrm{ind} . / \mathrm{m}^{2}$

The biomass of most Nerineoidea individuals is much larger than that of a single Turritella, and the possible number might therefore be much smaller. The contrary is the case: according to Allmon (1988) the number ranges generally between a few to $600 \mathrm{ind} . / \mathrm{m}^{2}$. Only exceptionally, 5000-10000 individuals have been calculated, which is in the range of the "Main Nerineoid Limestone" given by Waite et al. (2008).

\section{PalaeogeographicAl Distribution}

The restriction of the Nerineoidea to a circumequatorial belt of varying extension was first demonstrated by Neumayr (1881) and later by Dietrich (1925), Kauffman (1973), Sohl (1969, 1987) and Kollmann (1992). Their distribution therefore needs only a few additions. Neumayr (1883) was the first to recognize this belt as a palaeobiogeographic province and named it "Equatorial Province". Generally known under the incorrectly applied term "Tethys", it was re-named Theia by Kollmann (2002).

Because of its coral and rudist bioherms, this belt is considered as an equivalent of the presentday Tropical realm during the Cretaceous period (Kauffman 1973; Sohl 1971, 1987).

\section{NERINEOIDEA AND ACTEONELLOIDEA}

\section{The PHYlogeny Of THE NerineOIDEA}

The earliest recorded Nerineoidea are Ceritella welschi Cossmann, 1902 and Nerinella grossouvrei Cossmann, 1902 from the Early Jurassic (Hettangian) of the Vendeé (France). From the same period, Böhm (1884) described fragments of turriculate gastropods with strongly rebounding growth lines from northern Italy as Chemnitzia canossae Böhm, 1884. Although the aperture is incomplete, Dietrich (1925) probably correctly assigned this species to Pseudonerinea. Well-preserved specimens of the Late Jurassic Pseudonerinea clytia (d'Orbigny, 1851) show a comparable external morphology (Fig. 2A).

In the Middle Jurassic, more or less broadly umbilicate taxa with siphonal aureoles evolved within the Ceritellidae (Fischer 1959, 1961). Of these, Pseudotrochalia Cox, 1954 possesses a strongly convex final whorl, an acute siphonal aureole and a palatal plait (see Fischer 1959). The other morphological features agree with those of the turriform Fibuloptyxis Cossmann, 1898.

Equally in the Middle Jurassic, the coniform Cryptoplocinae Pchelintsev, 1960, which are the earliest Ptygmatididae, appear. The Ptygmatididae are often large and possess the most sophisticated plait structure among the Nerineoidea. Their umbilicus is surrounded by a moderately acute siphonal aureole. The Ptygmatididae became extinct in the Early 
Cretaceous. Pictet \& Campiche (1862) describe a number of internal moulds which indicate a range up the Aptian/Albian boundary.

The external morphology of Nerinella grossouvrei is almost the same as in the early Ceritellidae but differs by an obscurely angular periphery of the last whorl and three internal plaits. In stratigraphically later genera, the whorl periphery becomes distinctly angular. The Nerinellidae range stratigraphically into the Late Cretaceous (Campanian). In the Middle Jurassic they gave rise to the Eunerineidae n. fam.. Like the Ptygmatididae, the Eunerineidae n. fam. range stratigraphically into the Late Cenomanian.

The Nerineidae evolved from the Eunerineidae n. fam., of which some had become increasingly loosely coiled in late ontogenetic stages. The stratigraphically earliest Nerineidae species is the Bathonian Nerinea choffati Cossmann, 1898. It possesses three internal plaits, its whorl periphery is rounded and the base is tightly perforate. While it is morphologically still close to the Eunerineidae n. fam., the number of columellar plaits increased and the siphonal canal became larger and bent outwards, yielding a trumpet-like siphonal aureole in typical representatives of this family. The oviform Nerinea and the turriform Fibuloptygmatis Pchelintsev, 1965 extended into the Early Cretaceous (for example the Aptian Nerinea zumoffeni Delpey, 1940). From Fibuloptygmatis, the Cretaceous genera evolved. They dominate the assemblages from the Late Cenomanian upwards. Plesioptygmatis Boese, 1906 is restricted to Mexico and the Caribbean (Caribbean Province of Kauffman 1973).

Because of their totally different whorl sections, the Itieriidae cannot be an offshoot of the Nerineidae as Pchelintsev (1965) suggests. The family Itieriidae evolved in the Late Jurassic from the Ceritellidae (Cossmann 1896; Pchelintsev 1965). Late Jurassic taxa such as Ceritella polita (Sauvage \& Rigaux fide Cossmann, 1895) show a comparable, broadly rounded shell outline. Pchelintsev (1965) figured a turriculate specimen with a solid columella under Phaneroptyxis rugifera Zittel, 1873. The Early Cretaceous Eotrochactaeon Akopjan, 1976 is similar. In other Itieriidae genera the shells are much broader while the columella is hollow and enclosed by an aureole. In the Cretaceous genera Vernedia Mazeran, 1912 and Sogdianella Djaliliov, 1972 hollow lunulae are incorporated in the columella (Kollmann \& Sohl 1980) mark the limits of the siphonal beak in earlier growth stages.

\section{PERIODS OF SHELL ENLARGEMENTS}

Striking is the enormous increase in shell size in the families Eunerineidae n. fam., Nerineidae, Ptygmatididae and Itieriidae in the Oxfordian and the Kimmeridgian. Another period of enlargement is the Barremian with the diverse assemblage from Orgon, France (Cossmann 1907), and a final one took place from the Turonian onwards when the Eunerineidae n. fam. and the Ptygmatididae had died out and the Nerineidae flourished. With sizes up to $50 \mathrm{~cm}$, Laevinerinea Dietrich, 1939, Simploptyxis Tiedt, 1958 and Parasimploptyxis Akopjan, 1976 are the largest Nerineoidea genera known.

In general, the enlargement periods correspond with times of warming.

This is evident from $\delta 18_{\mathrm{O}}$ curves presented by Weissert et al. (2004) for the Late Jurassic and Early Cretaceous and by Gale (2000) for the Cretaceous. The occurrence of large Nerineoidea fits well with a warming pulse in the Oxfordian (Weissert et al. 2004) but not with the Early Kimmeridgian (Cossmann 1898) for which the $\delta 18_{\mathrm{O}}$ curve indicates a cooling. This may, however, be due to inaccuracies in the correlation.

\section{The ORIGIN OF THE NerineOIDEA}

Besides the Nerineoidea, Haszprunar (1985a) and Bandel (1996) allocated the Streptacidoidea Knight, 1931, Mathildoidea Dall, 1889, Pyramidelloidea Gray, 1840, Architectonicoidea Gray, 1850 and Valvatoidea Gray, 1840 to the Allogastropoda Haszprunar, 1985, informally termed Lower Heterobranchia. Beyond the heterostrophy, Haszprunar quotes shell solidity, an operculum (which actually has never been recorded) and columellar plaits in the Nerineoidea as indicative for this systematic position. The limited space within the shell, leaving a "narrow labyrinth", is reminiscent of the Pyramidelloidea. According to Schrödl et al. (2011), however, the Pyramidelloidea cluster with the Pulmonata. They have to 


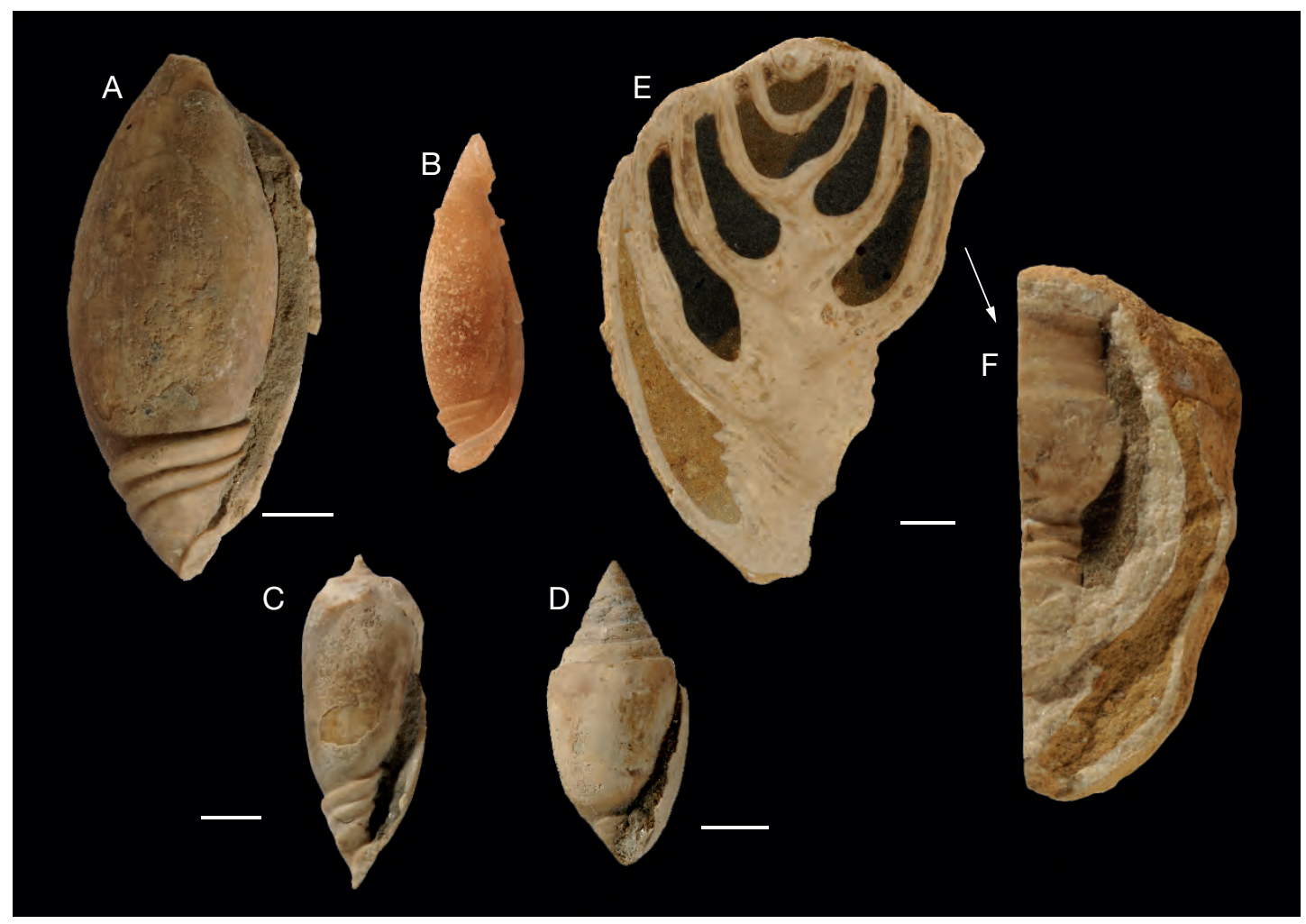

FIG. 12. - Acteonellidae: A, Acteonella styriaca Kollmann, 1965, Turonian, Gams bei Hieflau (Austria), figure from Kollmann 1965, NHMW 1965/664/13; B, Acteonella jicarensis Sohl \& Kollmann, 1985, Sabana Grande Quadrangle, Puerto Rico, Late Middle Maastrichtian, NHMW 2013/0267/0002; C, Neocylindrites gosaviensis Kollmann, 1967, Gams bei Hieflau (Austria), Turonian, NHMW1967/724/2; D, Trochactaeon lamarcki (Sowerby, 1831), Gams bei Hieflau (Austria), Turonian, NHMW 1836/II/18; E, F, Trochactaeon subglobosus (Münster, 1844); ?Campanian, Sebes, Romania, NHMW 1967/749; E, shows the resorbed columella; $\mathbf{F}$, furrows in the parietal wall might be traces of a posterior pallial cavity. Scale bars: $10 \mathrm{~mm}$.

be excluded from the Lower Heterobranchia and therefore cannot be related to the Nerineoidea.

Besides the family-specific features of the apertures, earliest Nerinelloidea agree remarkably in their external morphology. This postulates a parental group of more or less high-spired genera with adapically sinuate apertures in the Triassic. This is the case in Sinarbullina Gründel, 1997, Costacteon Gründel, 1997 and Domerionina Gründel \& Nützel, 2012. Gründel \& Nützel (2012) have allocated these genera to the Tubiferidae, but to me the before-mentioned morphological features seem representative for the Cylindrobullinidae Wenz, 1947, although their shells are not cylindrical like the typical representatives of the family.
THE ACTEONELLOIDEA, THE OTHER GROUP of LARGE MESOZOIC HeTEROBRANCHIA

The Cylindrobullinidae which are the earliest Acteonelloidea possess more or less cylindrical whorls, low to moderately high spires, moderately adapically reflected growth lines and a subsutural ramp (see Gründel \& Nützel 2012). The type species is C. fragilis (Dunker, 1846) from the Early Jurassic (Hettangian) of northern Germany (see Gründel 2010). Earliest Cylindrobullinidae date from the Late Triassic (Haas 1953; Gründel \& Nützel 2012). Taxa from the St. Cassian Formation described by Bandel (1994a) under Acteonina (A. lancadellia Bandel, 1994, A. stuorense Bandel, 1994) have to be included in this family. 
The Cylindrobullinidae were the parental group to Rugalindrites Gründel \& Nützel, 2012 (pro Cylindrites Morris \& Lycett, 1851). Because of its distinct subsutural notch and ramp and its columellar plaits, Rugalindrites represents the earliest Acteonellidae Gill, 1871 (see also Kollmann 1967). Occurrences in the Upper Middle Jurassic Great Oolite of Great Britain (Morris \& Lycett 1854), the Bathonian of France (Fischer 1969) and the Late Jurassic of the Crimea (Pchelintsev 1963) illustrate the wide distribution and diversity of this group. In the Early Cretaceous (Barremian), Rugalindrites gave rise to Neocylindrites Sayn, 1932 (see Kollmann 1967), which is almost identical with its ancestor but differs by 2-3 strong columellar plaits (Fig. 12C). In the Aptian, a lineage leads from Neocylindrites to the convolute Acteonella d'Orbigny, 1842 (Fig. 12A, B) with "Trochactaeon" subrenauxi Pchelintsev, 1953 as a transitional form. In the Cenomanian, another lineage leads from Neocylindrites to the turreted Trochactaeon, which invaded littoral environments in the Late Cretaceous. As in the Nerineoidea this was connected with an increase up to $30 \mathrm{~cm}$ (Figs 10D; 12D). The subsutural notch indicates a semi-infaunal mode of life. In contrast to the Nerineoidea and all other Acteonelloidea genera, traces of boring sponges and epibionts are abundant on Trochactaeon shells (Schremmer 1954; Herm \& Schenk 1971). Based on the boring sponges, Schremmer (1954) estimated living environments of 2 to $10 \mathrm{~m}$ depth. Winnowing during storm events has therefore commonly removed the surrounding sediment and accumulated the shells (Sanders et al. 1997). The shells which in contrast to the Nerineoidea were broadly convex may have been also partly uncovered from sediments the surface of the shells during lifetime. This is supported by the lack of a twisted siphonal canal or basal notch which would have elevated the inhalation opening and by the deposition of shell material in the adapical portion of the whorls (Fig. 10D) to protect these most vulnerable parts from abrasion (Kollmann 1967; Sohl \& Kollmann 1985).

The apertures of the Acteonelloidea are high and narrow and broadly excavated at the base. Adjacent to the subsutural notch, the whorl interior is enlarged by a broad, bipartite parietal depression

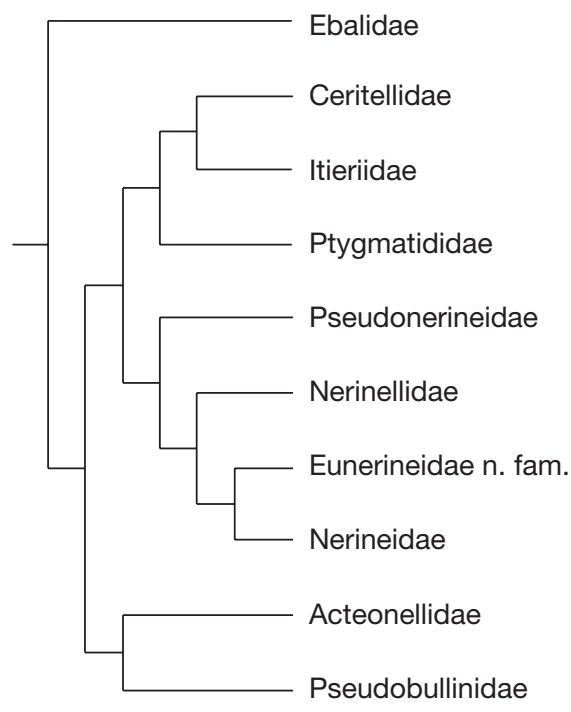

FIG. 13. - Intuitive cladogram: affinities between the Nerineoidea, the Acteonelloidea and the Streptacididae based on affinities of apertures.

(Fig. 12E, F). I have interpreted this as an impression of a posterior adductor muscle (Kollmann 1967) but because of its position adjacent to the siphonal notch it is more likely the impression of a posterior pallial cavity.

Aperture shape and the comparatively deep and broad subsutural notch reflect a position of the mantly cavity and the anus in a right posterior position, as Morton (1972) has described for example in the Anaspidean Akera bullata Müller, 1776. In Akera Müller, 1776 the shell is partly or totally covered by the mantle. This might have been also the case in the Acteonelloidea but cannot be proved.

\section{THE COMMON ORIGIN OF THE NERINEOIDEA} AND THE ACTEONELLOIDEA

From the Cylindrobullinidae (as conceived here) the lineage of the Acteonelloidea can be followed back in time to the earliest Triassic Jiangxispira Pan, Erwin \& Nützel, 2003. It possesses a fusiform shell with moderately convex, smooth whorls and the characteristic subsutural ramp. Pan et al. (2003) have pointed out the affinities to the Cylindrobullinidae and even left the possibility of an allocation to this family open. There is in fact a high coincidence of 
the teleconch with Sinarbullina, which Gründel \& Nützel (2012) allocated to the Tubiferidae (see above). Despite these affinities, Pan et al. (2003) allocated Jiangxispira to the Streptacididae because of the greater affinity of the protoconch. This would mean that both the Nerineoidea and the Acteonelloidea have evolved from the Streptacididae.

The Parallel EVOlution of the ACteOnOIDEA Cossmann (1895a), Wenz \& Zilch (1959), Bouchet \& Rocroi (2005) and Gründel \& Nützel (2012) have included the Acteonelloidea into the Acteonoidea. This cannot be upheld when the Acteonellidae originate from the Cylindrobullinidae. The main differences to the Acteonoidea are the subsutural notch and the smoothness of the shell, whereas the Acteonoidea are characterized by a sculpture of spiral grooves. This sculpture is a homologous morphological character persisting through geological times (see also Bandel 1994b). By considering the groove sculpture as a common feature, Mesozoic Acteonoidea would comprise the Bullinidae, the Acteonidae and the Ringiculidae in the sense of Gründel \& Nützel (2012). They would further include parts of the Tubiferidae, which Gründel \& Nützel conceive extremely broadly, and the "Opisthobranchia" by Kaim (2004).

The spiral sculpture supports the inclusion of the Early Carboniferous type species of Acteonina Meek (1863), A. carbonaria de Koninck, 1881 into the Acteonoidea and therefore into the Heterobranchia. This has been advanced by Knight (1936) and Kollmann \& Yochelson (1976) but has been more or less vehemently rejected (Bandel 1994a; Schröder 1996; Nützel et al. 2000; Pan et al. 2003; Gründel \& Nützel 2012). Bandel (1994a) stated that Acteonina was of "subulitid and thus of caenogastropod relation". Later, he allocated it to the Soleniscidae (Bandel 2002). This has to be ruled out for the following reasons: The original of A. carbonaria is a cylindrical internal mould which is shouldered adapically. Knight (1941) mentions remains of a spiral sculpture and Batten (1966) figures a cylindrical specimen with narrow whorls, a distinct subsutural ramp and a well-preserved spiral sculpture. In contrast, the shell of the Soleniscidae is aciculate to subglobular, and the aperture is tightly drop-shaped with a strong columellar plait. The shells are smooth or bear a sculpture of minute collabral ribs. The morphology therefore differs totally from Acteonina carbonaria, which actually resembles the Mesozoic Acteonoidea described by Haas (1953) and Gründel \& Nützel (2012). Information about the protoconch would certainly be desirable, but the preserved morphological features of the teleoconch are nonetheless highly conclusive for the Acteonoidea. The occurrence of Acteonoidea in the Palaeozoic is also supported by Acteonina permiana Hanger \& Strong, 1998 from the Early Permian Coyote Butte Formation of central Oregon, USA. Again, the heterostrophy is not explicitly recognizable because of the recrystallized protoconch. Although the sculpture is not preserved, the narrow aperture and the ramps of the whorls agree well with Triassic taxa of the Tubiferidae described by Haas (1953), which undoubtedly belong to the Acteonoidea. The only disturbing fact is the large time interval between the Early Permian and the first well-preserved Acteonoidea in the Late Triassic, which has not yet been bridged.

Due to ongoing molecular studies and a reassessment of anatomical characters, the systematics of the Heterobranchia are currently in flux (see Dayrat \& Tillier 2002; Vonnemann et al. 2005; Göbbeler \& Klussmann-Kolb 2011; Schrödl et al. 2011). Only the following points seem certain: The Streptacididae and their descendants constitute a polyphyletic group which first appeared in the Palaeozoic and cluster outside the Euthyneura (Schrödl et al. 2011).

\section{EXTINCTION OF THE NERINEOIDEA \\ AND ACTEONELLOIDEA \\ Fossil record}

Table 1 provides a synopsis of the first appearance/ extinction of Nerineoidea and Acteonellidae families in the Cretaceous.

In many cases, the processes are obscured by facies changes or cannot be dated precisely. An exception is the Late Cenomanian extinction event: In the Bohemian and Saxonian Basin (Czech Republic and Germany), Eunerinea was recorded up to the Late Cenomanian zone of Metoicoceras geslinianum (d'Orbigny, 1842) but not in younger deposits (Kollmann et al. 1998). Comparable stratigraphic ranges 
were recorded by Berthou (1973) from Portugal and by Djalilov (1977) from central Asia. Eunerinea is still present in the assemblage of Cherghes Rumania, allocated by Lupu (1965) to the Early Cenomanian. Equally, Delpey (1940) recorded 2 Nerineidae species (Parasimploptyxis requieni d'Orbigny, 1842 and P. olisiponensis Sharpe, 1850) from the Turonian of the Near East, in contrast to a diverse Cenomanian fauna. Abbass (1963) reported exclusively Early Cenomanian Nerineoidea assemblages from Egypt.

The extinction of the Eunerineidae n. fam. is a good stratigraphical marker. The Nerinellidae, Nerineidae and Itieriidae survive the Late Cenomanian extinction event. Members of these families became extinct at various times during the remaining Late Cretaceous periods and do not show a single extinction pattern. In the "basins" of the Alpine Gosau Group, the large Nerineidae Simploptyxis Tiedt, 1958 and Parasimploptyxis Akopjan, 1976 persist to the Late Santonian or Early Campanian (Summesberger et al. 2002; Kollmann, own observations). Parasimploptyxis was also recorded by Czabalay (1973) from Early Campanian deposits of Ugod and other localities in Hungary and by Marincas (1965) from Sebes, Rumania. Species from Armenia and Azerbaidjan, allocated to Plesioptygmatis by Pchelintsev (1954), actually belong to Parasimploptyxis. Parasimploptyxis geissuensis Pchelintsev, 1954, according to Pchelintsev of Late Senonian age, was dated as Coniacian by Akopjan (1976). The stratigraphic range of these taxa agrees with those of European localities. Reports on stratigraphically younger Nerineoidea from Europe are based on incorrect determinations, mostly of Campanileoidea possessing internal plaits like Nerineoidea but differing by their apertures (Vaughan 1988).

A specimen from the the Xigaze Group of Tibet, allocated by Wen (1988) to Plesioptygmatis, is not well preserved. Because of its considerable thickness, the recrystallized columella must have been hollow. The high and comparatively narrow whorls possessing five internal plaits represent an undeterminable taxon of the Ptygmatididae. The extinction of this family in the Aptian confirms Yü Wen's doubts about the Late Cretaceous age of the Xigaze Group.
TABLE 1. - Synopsis of first appearance/extinction of Nerineoidea and Acteonellidae families in the Cretaceous.

\begin{tabular}{ll}
\hline Time & $\begin{array}{l}\text { First appearance/ } \\
\text { extinction }\end{array}$ \\
\hline Barremian & $\begin{array}{l}\text { First appearance of the Acte- } \\
\text { onellidae genus Neocylindrites }\end{array}$ \\
Late Aptian & Extinction of the Ptygmatididae \\
& $\begin{array}{l}\text { Extinction of the Pseudonerinei- } \\
\text { dae, Ceritellidae and Eunerineidae } \\
\text { n. fam.; Appearance of the Acte- } \\
\text { onellidae genus Trochactaeon }\end{array}$
\end{tabular}

Early Campanian

Extinction of the Nerineidae in the Eastern Hemisphere; extinction of the Nerinellidae and the Acteonellidae genus Trochactaeon (except noded forms)

Early Maastrichtian

First appearance of Plesioptygmatis in the Caribbean Province.

Basal Late Maastrichtian

Extinction of Plesioptygmatis; first appearance of Mexticotrochactaeon in the Caribbean Province; extinction of Trochactaeon (noded forms)

Late Maastrichtian Extinction of Mexicotrochactaeon and Acteonella

A gastropod assemblage from the Zongshan Formation of the Kamba district of Tibet was first described by Douvillé (1916) and allocated to the Maastrichtian. Fragments of the large gastropod "Nerinea" ganesha Noetling, 1897 were removed from the Nerineoidea by Dietrich (1925) and transferred to the Campaniloidea. Douvillé described shell fragments under Acteonella crassa (Dujardin, 1835). Wen (1983), more cautiously, treated a sectioned specimen from the upper part of the Zongshan Formation with open nomenclature. The Tibetian specimens are apparently not as strongly inflated as $A$. crassa (see Kollmann 1965). In Trochactaeon? tuilaensis Wen, 1983 from the highest Cretaceous Jidula Formation, the internal plaits extend to the parietal region. It represents another gastropod group but is indeterminable. 
According to Saul \& Squires (1998), Nerineoidea younger than Turonian do not occur along the Pacific margin of North America. From the Atlantic side of the continent, Woodring (1952) described fragments which have been found reworked in Paleogene deposits of Cuba as Nerinea epelys Woodring, 1952. This species belongs to the Nerineidae genus Parasimploptyxis, which is widely distributed in the central and southern Europe and in the Caucasian region. Knipscheer (1938) identified this taxon as Nerinea bicincta Bronn, 1934. This species was originally described from the Late Cretaceous Gosau Group of the Eastern Alps (Maiersdorf Formation in Summesberger et al. 2002). According to Tiedt (1958) it is synonymous with the Late Santonian Parasimploptyxis buchi Münster, 1829. The Maastrichtian age assumed by Woodring remains to be proved. Specifically indeterminable axial sections of Plesioptygmatis, identified by Knipscheer from the same region as P. burckhardti Boese, 1906, do not co-occur with this species. Based on the Cenomanian Nerinea bauga d'Orbigny, 1842, Dietrich (1939) described the genus Laevinerinea Dietrich, 1939 and included specimens from Cuba into this species. The exact stratigraphic position of the much smaller Cuban specimens is unknown.

The Nerineidae genus Plesioptygmatis is known exclusively from Maastrichtian deposits of the Caribbean Province determined by Kauffman (1973). The type species, P. burckhardti, was recorded from the Upper Member of the Cardenas Formation (San Luis Potosi, Mexico), which is of Early Maastrichtian age (Omana et al. 2008). An undescribed specimen from the Early Late Maastrichtian El Rayo Fomation of Puerto Rico figured by Sohl (1987) under Nerinella sp. possesses two columellar plaits and a distinctly twisted siphonal canal (Fig. 5J). It represents a genuine Plesioptygmatis and is the stratigraphically youngest Nerineoidea taxon known. Plesioptygmatis became extinct in the Early Late Maastrichtian.

Stratigraphical data on Late Cretaceous Itieriidae are extremely scarce and not representative. There are only a few records of the Campanian to Maastrichtian Vernedia. These are Vernedia globoides (Stoliczka, 1867) from the Arrialoor group of India and "Itruvia" scalaris Vogel, 1902 from Borneo. Sogdianella Djalilov, 1972 was recorded from Cuba and Peru (Kollmann \& Sohl 1980) but the exact age is unknown.
As opposed to the Nerineoidea, the diversity of the Acteonelloidea increases after the Cenomanian (Sohl 1987). This is due to the evolution of the genus Trochactaeon in environments formerly inhabited by the Eunerineidae n. fam.. Trochactaeon develops extremely large shells. A typical representative is Trochactaeon ventricosus (Hojnos, 1921). The shells are almost globular and may reach sizes around $20 \mathrm{~cm}$ (see Figs 10D; 12E, F).

In the Eastern Hemisphere, the Acteonellidae (Trochactaeon, Neocylindrites, Acteonella) are scarce after the Campanian. Smith et al. (1995) quote Acteonella crassa (Dujardin) to extend into the Middle Maastrichtian in eastern Arabia (see also Morris \& Taylor 2000). The situtation is reversed in the Caribbean Province (Sohl \& Kollmann 1985). Mexicotrochactaeon Akopian, 1972 and a group of Acteonella possessing two instead of three columellar plaits (for example Acteonella jicarensis Sohl \& Kollmann, 1985 from Puerto Rico; Fig. 12B) are endemic to this marine palaeobiogeographic province. Studies of the Strontium isotope ratios by Steuber et al. (2002) indicate a late to latest Maastrichtian age for most Titanosarcolites limestones of Jamaica. In contrast to earlier biostratigraphic datings it is evident, that the Acteonellidae range stratigraphically up to the $\mathrm{K} / \mathrm{Pg}$ boundary exclusively in this faunal province.

To conclude, the final extinction of the Nerineoidea and Acteonellidae was a long-lasting and palaeogeographically differentiated process and not a single event.

\section{INTERPRETATION OF THE EXTINCTION EVENTS}

There is a remarkable congruency between the habitat and the Late Cretaceous climatic history. The MidCretaceous was one of the warmest periods in phanerozoic times, with surface water temperatures up to $36^{\circ} \mathrm{C}$ and atmospheric $\mathrm{CO}_{2}$ levels much higher than today (Forster et al. 2007; Pucéat 2008). From the Late Cenomanian on, temperatures increased steeply. In marine organisms, high temperatures can unbalance metabolic processes. This physiological disintegration (quoted after Levinton 1995) primarily affects stenothermic organisms that inhabit extremely shallow marine environments with restricted circulation. This clearly caused the late Cenomanian extinction of the Pseudonerineidae, Ceritellidae and Eunerineidae $\mathrm{n}$. fam. Major regressions that took place earlier in 
the Cenomanian (Wilmsen 2012) could not have caused the extinction.

The Acteonellidae genus Trochactaeon substitutes the extinct taxa ecologically. A remarkable size increase in the comparatively short time range of this genus may reflect the high nutrient production due to favourable climatic conditions. In the Santonian, the palaeo-sea surface temperatures dropped to about $33^{\circ}$ (Forster et al. 2007) and decreased further throughout the Campanian and Maastrichtian (Gale 2000; Burnett et al. 2000) with evidence of a seasonality (Steuber et al. 2005). The new conditions led to the extinction of the Old World Nerineidae and of Trochactaeon in the Campanian. Decreasing global temperatures caused Acteonella and Neocylindrites to retreat close to the circum-equatorial regions, where only a few species survived. Plesioptygmatis survived in the Caribbean Province until the basal Lower Maastrichtian, while Acteonella and Mexicotrochactaeon ranged up to the very Late Maastrichtian. There is, however, no indication that any of the Nerineoidea reached the $\mathrm{K} / \mathrm{Pg}$ boundary.

\section{RESULTS}

Within the heterobranch Nerineoidea the following families are distinguished based on their apertures and internal plications: Pseudonerineidae, Ceritellidae, Nerinellidae, Eunerineidae n. fam., Ptygmatididae, Nerineidae and Itieriidae. The Nerineidae in the sense of Pchelintsev were renamed into Eunerineidae $\mathrm{n}$. fam. The family name Diptyxidae applied to this group by Bouchet \& Rocroi (2005) cannot be upheld because Diptyxis belongs to the family Ceritellidae. Equally, Cossmannea is transferred from the Eunerineidae n. fam. to the Ceritellidae because of the siphonal notch of its type species, Cossmannea desvoidyi (d'Orbigny, 1842). Most species assigned to Cossmannea in the literature, however, possess a twisted siphonal canal and remain with Eunerinea Cox.

The subsutural notch and a rostrum supporting a siphonal canal or a siphonal notch indicate a semiinfaunal mode of life in all Nerineoidea except the Pseudonerineidae. The dimension and outline of the aperture indicate a small foot of squarish outline, which is characteristic for shell draggers.
I postulate that the internal plaits served at least two different functions: the columellar plaits separated strands of the columellar muscle. They also compensate the small size of the foot by a higher mobility of individually guided parts. The muscle strands must have been attached to the columella prior to the final $1 \frac{1}{2}$ whorls, in which the internal plaits become smaller or vanish completely. The smooth columellar lip of the Nerinellidae and Eunerineidae n. fam. suggests a high lateral mobility of the columellar muscle strands. The bipartite columellar lip in the Ptygmatididae indicates a reduced ability for lateral foot movement.

The parietal and the palatal plait delimit a tube-like chamber. This tube was connected by a narrow slit with remaining parts of the whorls and opened into the subsutural notch. It is interpreted as equivalent to the posterior chamber or pallial caecum of extant Heterobranchia, which runs dorsally towards the apex and provides an additional respiratory surface. In the Ptygmatididae the interior space prior to the final $1 \frac{1}{2}$ whorls was extremely constricted due to ramified and enlarged plaits. This left little space for viscera but enlarged the interior surface considerably. It is therefore interpreted as an enlargement of the respiratory surface. The rigid duct system described by Parker may have supported the mantle, which deposited aragonite layers in this part of the shell.

Because the earlier whorls were constricted, the last whorl must have accomodated at least a large part of the visceral mass. Although the internal space of the final $1 \frac{1}{2}$ increased because the plaits decreased or totally disappeared, the head-foot tract could probably not be withdrawn completely into the shell.

The Nerineoidea lived under tropical to subtropical conditions. Winnowing of the sediments through highenergy events accumulated shells in mass occurrences.

Compared with other Heterobranchia, both the Nerineoidea and the Acteonelloidea are exceptionally large. Both superfamilies evolved from the Streptacididae. The "Lower Heterobranchia" cluster outside the Euthyneura. Contrary to traditional interpretations, the Acteonellidae cannot be directly related to the Acteonoidea.

Both the Nerineoidea and the Acteonellidae became extinct during the Cretaceous. This was not a single event: After the extinction of the Ptygmatididae in the Aptian, a major extinction event occurred in the Late 
Cenomanian zone of Metoicoceras geslinianum, which the Pseudonerineidae, Ceritellidae and Eunerineidae n. fam. did not survive. This is interpreted to reflect the increase in global temperatures, which must have mainly affected taxa inhabiting shallow marine environments. In the Eastern Hemisphere, the Nerinellidae and Nerineidae became extinct in the ?Lower Campanian. Ecologically, the Acteonellidae genus Trochactaeon, Eunerineidae n. fam. which developed some species that were exceptionally large, replaced the Eunerineidae n. fam. in near-shore environments.

In the Eastern Hemisphere, the Nerineoidea and Trochactaeon became extinct in the Campanian, when the global temperatures decreased. The Itieriidae and Acteonella survived close to the equator until the MidMaastrichtian. The latest Nerineoidea representative was the Nerineidae genus Plesioptygmatis, which was endemic to the Caribbean palaeobiogeographic province and became extinct in the basal Lower Maastrichtian. In contrast to other regions, Acteonella and the endemic genus Mexicotrochactaeon ranged up to the Late Maastrichtian in this province.

\section{Acknowledgements}

It was a great experience for me to study the superb collection of Nerineoidea at the Muséum national d'Histoire naturelle in Paris during several visits, and I am extremely grateful to Didier Merle and Jean-Michel Pacaud for their constant support of my work. Andrzej Kaim has reviewed the paper, which benefitted considerably from his constructive proposals. I acknowledge the great support I had from the staff of the Department of Geology and Palaeontology at the Museum of Natural History in Vienna and want to express my sincere thanks to the head of this department, Mathias Harzhauser. Kriemhild Repp has transformed my sketches into decent figures, and Alice Schumacher has taken all photographs of material kept in the Viennese collection. The Nerineoidea and Acteonelloidea have occupied my interest for a long time and I was able to cooperate with many scientists on this and related fields. I dedicate this work to the late Jean-Claude Fischer and Norman F. Sohl, with whom I was not only connected by our common work but also by many years of friendship.

\section{REFERENCES}

ABbass H. L. 1963. - A Monograph on the Egyptian Cretaceous Gastropods. United Arab Republic, Geological Survey and Mineral Research Department, Geological Museum Monograph 2, 146 p.

AKopjan V. T. 1972. - Systematics of Late Cretaceous trochactaeonids (Gastropoda). Paleontologiceskii Zhurnal 1: 2-15.

AKOPJAN V. T. 1976. - Cretaceous Gastropods of the Armenian SSR. Akademia Nauk Arminskoj SSR, Yerevan, 415 p.

Allmon W. D. 1988. - Ecology of Recent Turritellinae Gastropods (Prosobranchia, Turritellidae): Current Knowledge and Paleontological Implications. Palaios 3: 259-284.

Aliev G. K. \& LysEnKo N. I. 1986. - Baku, on the taxonomy of the Nerinellidae. Doklady Akademii Nauk Azerbaidjanskoi SSR 42 (5): 60-65.

BANDEL K. 1994a. - Triassic Euthyneura (Gastropoda) from St. Cassian (Italian Alps) with a discussion on the evolution of the Heterostropha. Freiberger Forschungshefte C 452: 79-100.

BANDEL K. 1994b. - Comparison of Upper Triassic and Lower Jurassic gastropods from the Peruvian Andes (Pucará Group) and the Alps (Cassian Formation). Palaeontographica, Abteilung A 233: 127-160.

BANDEL K. 1996. - Some heterostrophic gastropods from Triassic St. Cassian Formation with a discussion on the classification of the Allogastropoda. Paläontologische Zeitschrift 70: 325-365.

BANDEL K. 2002. - Reevaluation and classification of Carboniferous and Permian Gastropoda belonging to the Caenogastropoda and their relation. Mitteilungen des Geologisch-Paläontologischen Instituts der Universität Hamburg 86: 81-188.

BARKER M. J. 1990. - The palaeobiology of nerineacean gastropods. Historical Biology 3: 249-264.

BATTEN R. L. 1966. - The Lower Carboniferous Gastropod Fauna from the Hotwells Limestone of Compton Martin, Somerset. Palaeontological Society Monographs, London, 119: $109 \mathrm{p}$.

Berthou P. Y. 1973. - Le Cénomanien de l'Estrémadure Portugaise. Servicios Geologicos de Portugal, Lisboa, Memoria 23 (n.s.), 162 p.

Bigot A. 1896. - Nerinaeidées du Séquanien de Cordebugle (Calvados). Bulletin de la Societé géologique de France, ser. 3, 24: 29.

BöHм G. 1884. — Beitrag zur Kenntnis der grauen Kalke in Venetien. Zeitschrift der deutschen Geologischen Gesellschaft 36: 737-782.

Boese E. 1906. - La fauna de Molluscos del Senoniano de Cardenas, San Luis Potosi. Boletín del Instituto Geológico de México 24: 1-95.

BOUCHET P. \& ROCROI J.-P. 2005. - Classification and Nomenclator of Gastropod Families. Malacologia 47 (1-2), $397 \mathrm{p}$. 
BRACE R. C. 1977. - The functional anatomy of the mantle complex and columellar muscle of Tectibranch molluscs (Gastropoda: Opisthobranchia), and its bearing on the evolution of Opisthobranch organization. Philosophical Transactions of the Royal Society of London, ser. B (Biological Sciences) 277: 1-54.

BurnetT J. A., YounG J. R. \& BROWN P. R. 2000. Calcareous nannoplankton and global climate change, in Culver ST. J. \& Rawson P. F. (eds), Biotic response to Global Change: The Last 145 Million Years. Cambridge University Press. Cambridge University Press, Cambridge: $35-50$.

Cossmann M. 1895a. - Essais de Paléoconchologie comparé 1, 159 p. (published by the author).

Cossmann M. 1895b. - Contribution à la Paléontologie Francaise des Terrains Jurassiques. Études sur les Gastropodes des Terrains Jurassiques. Mémoires de la Societé Géologique de France, sér. Paléontologie 14, 112 p.

Cossmann M. 1896. - Essais de Paléoconchologie comparé 2, 179 p. (published by the author).

Cossmann M. 1898. - Contribution á la Paléontologie Francaise des Terrains Jurassiques. Gastropodes: Nérinées. Mémoires de la Societé Géologique de France, sér. Paléontologie 19, $179 \mathrm{p}$.

Cossmann M. 1902. - Paléontologie, in ChraTRON C. \& Cossmann M. (eds), Note sur l'Infalies de la Vendée et spécialement sur un gisement situé dans la commune du Simon-La-Vineuse. Bulletin de la Société Géologique de France, Sér. 4, vol. 2: 163-203.

Cossmann M. 1907. - Description des gastropode et pélécypodes, in Pellat E. \& Cossmann M. (eds), Le Barrêmien supérieur à faciés Urgonien de BrouzetLez-Alais Gard). Mémoires de la Société Géologique de France, sér. 15, 1: 6-42.

Cotaldo C. S. 2013. - A new Early Cretaceous nerineoid gastropod from Argentina and its palaeobiogeographic and palaeoecological implications. Cretaceous Research 40: 51-60.

Cox L. R. 1949. - On the genotype of Nerinea; with a new subgeneric name Eunerinea. Proceedings of the Malacological Society of London 27: 248-250.

Cox L. R. 1964. - Gastropoda-General characteristics of gastropoda, in Moore R. C. \& PITRAT W. (eds), Treatise on Invertebrate Paleontology, Part I, Mollusca. University of Kansas Press and the Geological Society of America, Kansas and New York: i84-i170.

CZABAlaY L. 1973. - [The gastropods of the Aptian, Albian and Cenomanian of the Bakony Mountains (Hungarian Central Massif)] A Sümegi Szenon zátonyfácies Actaeonella és Nerinea faunája (Actaeonella and Nerinea fauna of the Senonian reef facies at Sümeg). Magyar Állami Földtani Intézet Ėvi Jelentése 1973: 285-299 (in Hungarian).

DACQUÉ E. 1921. - Vergleichende biologische Formenkunde der fossilen niederen Tiere. Borntraeger, Berlin, 777 p.
DALL W. H. 1894. - The mechanical cause of folds in the aperture of the shell of Gasteropoda. American Naturalist 28: 909-914.

Dauwalder P. \& Remane J. 1979. — Étude de Banc à Nérinées à la limite "Kimmeridgian-Portlandien" dans le Jura Neuchâtelois méridional. Paläontologische Zeitschrift 53: 163-181.

DAYRAT B. \& Tillier S. 2002. - Evolutionary relationship of euthyneuran gastropods (Mollusca): a cladistics re-evaluation of morphological characters. Zoological Journal of the Linnean Society 135: 403-470.

DELPEY G. 1937. - Symbiose d'une Nerninée et d'un Hydrozoaire. Bulletin de la Societé géologique de France, sér 5, 7: 353-358.

DelPey G. 1940. — Les Gastéropodes mésozoiques de la Région libanaise. Service des travaux publics, Section d'études géologiques, Notes et Mémoires 3: 5-292

Deshayes P. G. 1827. - Nerina mosae. Dictionnaire classique d'Histoire Naturelle 11: 534-535.

DieTL G. \& Vega F. J. 2008. — Spezialized shellbreaking crab claws in Cretaceous seas. Biological Letters 4: 290-293.

DiETRICH W. O. 1925. — Gastropoda mesozoica: fam. Nerineidae, in JunK W. (ed.), Fossilium Catalogus: Animalia. Vol. 1. W. Junk, Berlin, 164 p.

DieTriCH W.O. 1939. - Laevinerinea nov. subg. aus der Oberkreide von Trinidad. Paläontologische Zeitschrift 21: 131-135.

DJALILOV M. R. 1972. — [The systematics of Acteonellidae (gastropoda)] K sistematike Acteonellid (gastropoda). Paleontologiceskii Jurnal 1: 16-23. (in Russian).

DJALILOV M. R. 1977. - [Cretaceous gastropods of southeast Cebtral Asia] Melovye bruchonogije jugo-vostoka Credniej Azji. Akademia Nauk Tadzyckoj SSR-Institut Geologii, Duszanbe, 202 p. (in Russian).

Douvillé H. 1916. — Le Crétacé et l'Éocène du Tibet Central. Memoirs of the Geological Survey of India, Palaeontologica Indica, n.s., 5 (3), 83 p.

DUNKER W. 1846. - Diagnosen einiger neuer Conchylien aus der norddeutschen Liasbildung. Zeitschrift für Malakozoologie 3: 168-171.

FISCHER J.-Cl. 1959. - Description de quatre espèces nouvelles des genres fossiles Pseudotrochalia Cox et Fibuloptyxis Cossmann. Journal de Conchyliologie 99: 201-209.

FISCHER J.-CL. 1961. - Sur l'apparation des Ceritellidae au Charmouthien, avec la proposition d'un genre nouveau, Proceritella. Journal de Conchyliologie 101: 135-154.

FisCHER J.-CL. 1969. - Géologie, paléontologie et paléoécologie du Bathonien au sud-ouest du Massif Ardennais. Mémoires du Muséum national d'Histoire naturelle, n.s., 20: 1-319.

Forster A. St., BaAs M. \& Sinninghe Damsté M. 2007. - Mid-Cretaceous (Albian-Santonian) sea surface temperature record of the tropical Atlantic ocean. Geology 35 (10): 919-922. 
Fretter V. \& Graham A. 1954. - Observations on the opisthobranch mollusc Acteon tornatilis (L.). Journal of the Marine Biology Association 33: 565-585.

Gale A. 2000. - The Cretaceous world, in Culver St. J. \& Rawson P. F. (eds), Biotic Response to Global Change: The Last 145 Million Years. Cambridge University Press, Cambridge: 4-19.

Göbbeler K. \& Klussmann-Kolb A. 2011. - Molecular phylogeny of the Euthyneura (Mollusca, Gastropoda) with special focus on Opisthobranchia. Thalassas 27: 121-154.

GRÜNDEL J. 1997. — Heterostropha (Gastropoda) aus dem Dogger Norddeutschlands und Nordpolens. III. Opisthobranchia. Berliner geowissenschaftliche Abhandlungen E25: 177-223.

GRÜNDEL J. 2006. — Gastropoden aus dem oberen Bathonium von Luc-sur-Mer/Calvados (Normandie, Frankreich) III. Heterostropha. Freiberger Forschungshefte C 511: 1-30.

GRÜNDEL J. 2010. — Neubeschreibung der Gastropodenfauna aus dem Hettangium (unterster Jura) des Kanonenberges bei Halberstadt (Deutschland). Beringeriana 41: 3-24.

GRÜNDEL J. \& NÜtZEL A. 2012. - On the early evolution (Late Cretaceous to Late Jurassic) of the Architectibranchia (Gastropoda: Heterobranchia), with a provisional classification. Neues Jahrbuch für Geologie und Paläontologie, Abhandlungen 264 (1): 31-59.

HAAS O. 1953. - Mesozoic invertebrate faunas of Peru. Bulletin of the American Museum of Natural History 101: 1-328.

Hanger R. A. \& Strong E. E. 1998. - Acteonina permiana, a new species from the Permian Coyote Butte Formation, central Oregon (Mollusca: Gastropoda, Actaeonidae). Proceedings of the Biological Society of Washington 111 (4): 795-798.

HASZPRUNAR G. 1985a. - The Heterostropha - a new concept of the phylogeny of the higher Gastropoda. Zeitschrift für zoologische Systematik und Evolutionsforschung 23: 15-37.

HASZPRUNAR G. 1985b. - On the anatomy and systematic position of the Mathildidae (Mollusca, Allogastropoda). Zoologica Scripta 14: 201-213.

Herm D. 1977. - Zyklische Regressions-Sedimentation und Fossil-Vergesellschaftungen in der Gosau (Santonium) von Brandenberg/Tirol. Mitteilungen der Bayerischen Staatssammlung für Paläontologie und Historische Geologie 17: 257-277.

Herm D. \& Schenk V. 1971. — Parasitäre Epökie von Radiolites auf Trochactaeon. Neues Jahrbuch für Geologie und Paläontologie 6: 324-339.

HojNOS R. 1921. — Oberkretazische Gastropoden aus dem Komitate Arad. Földtani Közlöny 50 (1920): 89-98.

HoubRICK R. S. 1981. — Anatomy, biology and systematics of Campanile symbolicum with reference to adaptive radiation of the Cerithiacea (Gastropoda: Prosobranchia). Malacologia 21 (1-2): 263-289.

Houbrick R. S. 1984. — The Giant Creeper, Campanile symbolicum Iredale, an Australian Relict Marine Shell, in ELDRIDGE N. \& STANLEY ST. M. (eds), Living Fossils. Springer Verlag, New York, 232-235.

Houbrick R. S. 1991. - Systematic review and functional morphology of the Mangrove snails Terebralia and Telescopium (Potamididae; Prosobranchia). Malacology 33 (1-2): 289-338.

HuCKRIEDE R. 1967. - Molluskenfaunen mit limnischen und brackischen Elementen aus Jura, Serpulit und Wealden NW-Deutschlands und ihre paläogeographische Bedeutung. Beihefte zum Geologischen Jahrbuch 67: 1-263.

HUdLESTONE W. H. 1887-1896. - A Monograph of the Inferior Oolite Gastropoda. Palaeontographical Society, London, $514 \mathrm{p}$.

IshiKaWA M., KaSE T., Tsutsui H. Z. \& Tojo B. 2004. Snails versus hermit crabs: a new interpretation on shell-peeling predation in fossil gastropod assemblages. Paleontological Research 8 (2): 99-109.

JENSEN K. R. 1996. - Comparative morphology of the mantle cavity organs of shelled Sacoglossa, with a discussion of relationships with other Heterbranchia. Thalassas 27 (2): 169-192.

KaIM A. 2004. - The evolution of conch ontogeny in Mesozoic open sea gastropods. Palaeontologia Polonica 62: 1-183.

Kauffman E. G. 1973. — Cretaceous Bivalvia, in HaLLAM A. (ed.), Atlas of palaeobiogeography: 353-363.

Kay A., Wells F. E. \& Ponder W. F. 1998. - Class Gastropoda, in BeEsley P. L., Ross G. J. B. \& Wells A. (eds), Mollusca: The Southern Synthesis. CSIRO Publishing, Melbourne, Fauna of Australia, vol. 5, part B: viii, 565-1234.

KNIGHT J. B. 1936. - Notes on Paleozoic Gastropoda. Journal of Paleontology 10: 50-534.

KNIGHT J. B. 1941. - Paleozoic gastropod genotypes. Geological Society of America, Special Papers 32: 510 p.

KNIPSCHEER H. 1938. - On cretaceous Nerinea's from Cuba. Proceedings of the Section of Sciences 46: 671-676.

Kollmann H. A. 1965. - Actaeonellen (Gastropoda) aus der ostalpinen Oberkreide. Annalen des Naturhistorischen Museums Wien 68: 243-262.

Kollmann H. A. 1967. — Die Gattung Trochactaeon in der ostalpinen Oberkreide. Zur Phylogenie der Actaeonellidae. Annalen des Naturhistorischen Museums Wien 71: 199-261.

KollmanN H. A. 1982. - Cenomane Gastropodenfaunen aus dem Ophiolith-Konglomerat Böotiens (Griechenland). Annales géologiques des Pays helléniques 31:333-358.

Kollmann H. A. 1992. - Distribution of gastropods within the Cretaceous Tethyan realm. Schriftenreihe der Erdwissenschaftlichen Kommissionen der Österreichischen Akademie der Wissenschaften 9: 95-128. 
Kollmann H. A. 2002. - Theia and Kalais - Paleobiogeographic terms replacing Tethys and Boreal, in Michalik J. (ed.), Tethyan/Boreal Cretaceous Correlation. Veda, Bratislava: 285-291.

Kollmann H. A. 2005. - Marine Palaeobiogeography of the Central European Late Cretaceous. Bulletin of the Geological Society of Denmark 52: 193-199.

Kollmann H. A. \& Yochelson E. L. 1976. - Survey of Paleozoic gastropods possibly belonging to the subclass Opisthobranchia. Annalen des Naturhistorischen Museums Wien 80: 207-220.

Kollmann H. A., Decker K. \& LeMone D. 2003. Facies control of Lower Cretaceous gastropod assemblages, southwestern United States, in SCOTT R. W. (ed.), Cretaceous Stratigraphy and paleoecology, Texas and Mexico: Perkins Memorial Volume. Gulf Coast Section, Society of Economic Palaeontologists and Mineralogists Foundation, Special Publication in Geology 1: 101-146.

Kollmann H. A. \& Peza L. H. 1997b. - Diptyxis Oppenheim (Nerineacea, Gastropoda) from the Lower Cretaceous of Albania. On the distribution of the genus Diptyxis. Annalen des Naturhistorischen Museums Wien 98A: 17-33.

Kollmann H. A., Peza L. \& Cech St. 1998. - Upper Cretaceous Nerineacea of the Bohemian Basin (Czech Republic) and the Saxonian Basin (Germany) and their significance for Tethyan environments. Abhandlungen des Staatlichen Museums für Mineralogie und Geologie zu Dresden 43/44: 151-172.

Kollmann H. A. \& SoHL N. F. 1980. — Western hemisphere Cretaceous Itieriidae gastropods. Geological Survey Professional Paper 1135-A: A1-A15.

KonINCK L.- G. DE 1881. — Faune du calcaire carbonifère de la Belgique, 3e partie: Gastéropodes. Annales du Musée royal d'Histoire naturelle de Belgique, série paléontologique 6: $170 \mathrm{p}$.

KOUYOUMONTZAKIS G. 1987. — Paléobiogéographie et Paléoécologie des Nerineidae (Gastropoda) du Crétacé Supérieur de Provence, Bassin du Beausset (Var, France, S.W.). Géologie Méditerranéenne 12-13: 13-27.

KowalKe TH. \& BANDEl K. 1996. - Systematik und Paläoökologie der Küstenschnecken der nordalpinen Brandenberg-Gosau (Oberconiac/Untersanton) mit einem Vergleich zur Gastropodenfauna des Maastrichts des Trempbreckens (Südpyrenäen, Spanien). Mitteilungen der Bayerischen Staatssammlung für Paläontologie und historische Geologie 36: 15-71.

KRIVIC K. 1974. - Nerineidae of Trnovski Gozd and Banjška Planota. Geologija-Razprave in Poročila 17: 181-227.

LEVINTON J. S. 1995. - Marine Biology. Oxford University Press, New York, Oxford, 420 p.

LORIOL P. DE 1890. — Études sur les mollusques des couches coralligènes inférieures du Jura Bernois. Deuxième partie. Mémoires de la Société paléontologique Suisse 17: 81-174.
LORIOL P. DE 1889-1892. — Études sur les mollusques des couches coralligènes inférieurs du Jura bernois. Mémoires de la Société paléontologique Suisse 16-19: $1-419$.

LuPu D. 1965. - Studiul faunei de gasteropode cenomanienne de la Cherghes. Studii si Cercetari de Geologie, Geofizika, Geografie, Serie Geologie 10 (1): 47-60.

LysSENKO N. I. \& Aliev G. A. 1987. - [Revision of the genus Diozoptyxis and a new family of gastropods] Revizija roda Diozoptyxis i novoe semejstwo gastropod. Paleontologiceskii Zhournal 1987 (1): 116-120.

LYSSENKO N. I \& KOROTKOV V. A. 1992. — [On a new nerineid suborder (Gastropoda)] O novom podotrjade nerineid (Gastropody). Paleontologiceskij Jurnal 1992 (4): 17-22.

McNair C. G., Kier W. M., LaCroix P. D. \& Linsley R. M. 1981. - The functional significance of aperture form in gastropods. Lethaia 14: 63-70.

Malaquias M. A. E. \& Sprung M. J. 2005. - Population biology of the Cephalaspidean mollusc Haminoea orbignyana in a temperate coastal lagoon (Ria Formosa, Portugal). Estuarine, Coastal and Shelf Science 63 (1-2): 177-185.

MarinCAS V. 1965. - Nerineele din Facieul Gosau de la Sebes. Studie Universitatis Babes-Bolyai, Serie Geologia-Geographia 1: 65-78.

Meek F. B. 1863. - Remarks on the family Actaeonidae, with descriptions of some new genera and subgenera. American Journal of Science 35: 89-94.

MiKKELSEN P. M. 2002. - Shelled Opisthobranchs. Advances in Marine Biology 42: 67-136.

MORRIS F. G. S. \& LYCETT J. 1854. - Monograph of the Mollusca from the Great Oolite, Chiefly from Minchinhampton. Palaeontographical Society, London, 147 p.

MORRIS N. \& TAYLOR J. 2000. — Global events and biotic interaction as controls on the evolution of gastropods, in Culver ST. J. \& RaWson P. F. (eds), Biotic response to Global Change: The Last 145 Million Years. Cambridge University Press, Cambridge: 149-163.

MorTON J. E. 1972. - The Form and Functioning of the Pallial Organs in the Opisthobranch Akera bullata with a Discussion on the Nature of the Gill in Notaspidea and other Tectibranchs. The Veliger 14 (4): 337-349.

NEUMAYR M. 1881. — Über klimatische Zonen während der Jura- und Kreidezeit. Denkschriften der kaiserlichen Akademie der Wissenschaften, mathematisch-naturwissenschaftliche Klasse 57: 277-310.

NÜTZEL A., ERWIN D. H. \& MAPES R. H. 2000. - Identity and phylogeny of the Late Paleozoic Subulitoidea (Gastropoda). Journal of Paleontology 74 (4): 575-598.

Omana L., Pons J. M. \& Alencaster G. 2008. Latest Cretaceous foraminifera from the Cardenas Formation, San Luis Potosi, Mexico: Stratigrapical, paleoenvironmental and paleobiogeographical significance. Micropaleontology 54 (5): 445-462. 
OpPenheim P. 1889. - Beitrage zur Geologie der Insel Capri und der Halbinsel Sorrent. Zeitschrift der Deutschen Geologischen Gesellschaft 41: 442-490.

Orbigny A. DE 1842-1843. - Paléontologie francaise. Terrains crétacés. Vol. 3: Gastéropodes. Arthus-Bertrand Ed., Paris, 456 p.

ORBIGNY A. DE 1850-1852. - Prodrôme de Paléontologie stratigraphique universelle des animaux mollusques et rayonnés. Masson Ed., Paris. Vol. 1 (1850, 394 p.), Vol. 2 (1850, 427 p.) and Vol. 3 (1852, 194 p.).

OrbignY A. DE 1851-1860. - Paléontologie Francaise, Terrains jurassiques. Vol. 3: Gastéropodes. Masson Ed., Paris, $621 \mathrm{p}$.

Pan H.-Z., ERWIN D. H., NÜTZEl A. \& Zhu X.-S. 2003. - Jiangxispira, a new gastropod genus from the Early Triassic of China with remarks on the Phylogeny of the Heterostropha at the Permian/Triassic boundary. Journal of Paleontology 77 (1): 44-48.

PCHELINTSEV V. F. 1931. - [ Gastropoda from the Upper Jurassic and Lower Cretaceous beds of the Crimea] Brjuchonogie werchnej Jury i niznego mela Krima. Glavnoe GeologoRaswedocnoe Upravle, Moskwa-Leningrad, 252 p.

PCHelintseV V. F. 1953. - [Gastropod Fauna of Transcaucasia and Middle Asia] Fauna bryukhogikh verkhemelovikh Otlozhenij Zakawkasja srednei Azii. Akademie Nauk SSR, Moskwa-Leningrad, 391 p.

PCHELINTSEV V. F. 1954. - [Gastropods from the Upper Cretaceous Deposits of the Armenian SSR and of the Borderung Areas of the Azerbaydzhan SSR] Brjuchonogie Werchnemelovich Otlozenii Armjainskoj SSR i Prjlegajushej Tsasti Azerbajdshanskoj SSR. Akademia NAUK SSR, Moskwa-Leningrad, 178 p.

PCHeLINTSEV V. F. 1960. - Superfamily Murchisoniacea, in PCHELINTSEV V. F. \& KorobKOV I. A. (eds), Fundamentals of Palaeontology, Mollusca-Gastropoda. Governmental technical-scientific printing company, Moskwa, 360 p.

PCHELINTSEV V. F. 1963. - Brjuchonogie Mesozoja Gornogo Kryma. Akademia Nauk SSSR, Leningrad, 130 p.

PCHELINTSEV V. F. 1965. - Mesozoic Murchisoniata from the Crimean Highland. Nauka, Moskwa, 216 p.

Peron M. P. 1901. - Sur les Nérinées jurassiques et la structure de leur coquille. Comptes rendus de la association francaise pour l'avancement des Sciences, Congrès d'Ajaccio, part. 1: 147-148.

PiCTET F.-J. \& CAMPICHE G. 1861-1864. — Descripion des fossiles du terrain crétacé des environs de Sainte-Croix. 2nd part. H. Georg, Genève, 752 p.

PietTe E. 1864-1891. - Paléontologie francaise, Terrain jurassique. Vol. III. Gastropodes. Masson, Paris, 535 p.

Ponder W. F. \& Warén A. 1988. - Appendix; classification of the caeonogastropoda and Heterostropha - a list of the family-group names and higher taxa. Malacological Review, supplement 4: 288-326.

PRICE R. M. 2003. - Columellar muscle of neogastropods: muscle attachment and the function of columellar folds. Biological Bulletin 205: 351-366.

PUCÉAT E. 2008. - A new breath of life for anoxia. Geology 36 (10): 831, 832.

SÄlgeback J. \& SAVAZZi E. 2006. - Constructional morphology of cerithiform gastropods. Paleontological Research 10 (3): 233-259.

Sanders D., Kollmann H. A. \& Wagreich M. 1997. Sequence development and biotic assemblages on an active continental margin: the Turonian-Campanian of the Northern Calcareous Alps, Austria. Bulletin de la Société Géologique de France 168: 351-372.

SAUL L. R. \& SQUiRES R. L. 1998. - New Cretaceous gastropoda from California. Palaeontology 42 (3): 461-488.

SaUl L. R. \& SQuires R. L. 2002. — Added Nerineoid gastropod evidence for a warm Turonian sea in southern California. Journal of Paleontology 76 (2): 386-390.

SAYN G. 1932. - Description de la faune de l'Urgonien de Barcelonne (Drôme). Travaux du Laboratoire de Géologie de la Faculté des Sciences de Lyon, Fascicule 18, Mémoire 15: 1-67.

SCHÄFER R. 1962. - Aktuo-Paläontologie nach Studien in der Nordsee. Waldemar Kramer, Frankfurt, 666 p.

SCHREMMer F. 1954. - Bohrschwammspuren in Actaeonellen aus der nordalpinen Gosau. Sitzungsbericht der Österreichischen Akademie der Wissenschaften, Mathematisch-naturwissenschaftliche Klasse, Abteilung 1 (4-5): 297-300.

SCHRÖDl M., JÖRGER K. M., KlusSMANN-Kolb A. \& WiLsOn N. G. 2011. — Bye Bye "Opisthobranchia”! A review on the contribution of mesopsammic sea slugs to euthyneuran systematics. Thalassas 27 (2): 101-112.

SCHRÖDER M. 1996. — Frühontogenetische Schalen jurassischer und unterkretazischer Gastropoden aus Norddeutschland und Polen. Palaeontographica A 238: 1-95.

SHARPE D. 1850. - Remarks on the genus Nerinea with an account of the species found in Portugal. Quarterly Journal of the Geoogical Society London 6: 101-114.

SHIKAMA T. \& YUI S. 1973. - On some nerineid Gastropoda in Japan (preliminary report). Scientific Reports of the Yokahoma National University, section C, 20: 9-57.

Signor Ph. W. \& KAT P. W. 1984. - Functional significance of columellar folds in turritelliform gastropods. Journal of Paleontology 58: 210-210.

SIRNA G. 1995. — The Nerineids: Taxonomy, stratigraphy and paleoecology with particular references to Italian examples. Geologica Romana 31: 285-305.

Sirna G. \& MASTROIANNI F. 1993. - Jurassic-Cretaceous nerineids of Campoli Appennino (Latium). Geologica Romana 29: 139-153.

Smith A. B., Morris N. J., Gale A. S. \& Rosen Br. R. 1995. - Late Cretaceous (Maastrichtian) echinoidmollusc-coral assemblages and palaeoenvironments from a Tethyan carbonate platform succession, northern Oman. Palaeogeography, Palaeoclimatology, Palaeoecology 119: 155-168. 
SoHL N. F. 1969. - North American biotic provinces delineated by gastropods. Proceedings of the North American Paleontological Convention L: 1610-1638.

SoHL N. F. 1987. — Presidential Address: Cretaceous gastropods. Contrasts between Tethys and the temperate provinces. Journal of Paleontology 61 (6): 1085-1111.

Sohl N. F. \& Kollmann H . A. 1985. - Cretaceous Actaeonellidae Gastropods from the Western Hemisphere. US Geogical Survey, Professional Paper 1304, $104 \mathrm{p}$.

Steuber Th., Mitchell S. F., Buhl D., Gunter G. \& KAsper H. U. 2002. - Catastrophic extinction of Carribean rudist bivalves at the Cretaceous-Tertiary boundary. Geology 30 (11): 999-1002.

Steuber Th., Rauch M., Masse J.-P., Graaf J. \& MALKOC M. 2005. — Low-latitude seasonality of Cretaceous temperatures in warm and cold episodes. Nature 437: 1341-1344.

STOLICZKA F. 1867-68. - Cretaceous fauna of southern India, vol. 2: The gastropoda of the Cretaceous rocks of southern India. Memoirs of the Geological Survey of India, Palaeontographica Indica 5 (2), 497 p.

Summesberger H., Wagreich M., Tröger K.-A. \& Scholger R. 2002. - The Upper Cretaceous of Piesting (Austria): Integrated stratigraphy of the Piesting Formation (Gosau Group). Österreichische Akademie der Wissenschaften, Schriftenreihe der Erdwissenschaftlichen Kommission 15: 373-399.

TAYLOR J. D., MORRIS N. J. \& TAYLOR C. N. 1980. Food specialization and the evolution of predatory prosobranch gastropods. Palaeontology 23: 375-409.

Thompson J. T., Lowe A. D. \& Kier W. M. 1998. The columellar muscle of prosobranch gastropods: morphological zonation and its functional implications. Invertebrate Biology 117 (1): 45-56.

THURMANN J. 1832. - Essai sur les soulèvements jurassiques du Porrentruy. Mémoires de la Société d'Histoire naturelle Strasbourg, Paris, $84 \mathrm{p}$.

TiedT L. 1958. — Die Nerineen der österreichischen Gosauschichten. Sitzungberichte der Österreichischen Akademie der Wissenschaften., Mathematisch-naturwissenschaftliche Klasse, Abt. 1, 167: 483-517.

Vaughan P. G. 1988. - Cretaceous Nerineacean Gastropods: Systematics, Affinities and Palaeoecology. Thesis, Department of Earth Sciences, Open University, 264 p.

Vermej G. J. 1977. — The Mesozoic marine revolution: evidence from snails, predators and grazers. Paleobiology 3: 245-258

Vermej G. J. 1987. - Evolution and Escalation. A Ecological History of Life. Princeton University Press, Princeton, $526 \mathrm{p}$.

Vogel K. 1968. - Zur Lebensweise des Gastropoden Nerinea. Neues Jahrbuch für Geologie und Paläontologie, Monatshefte 3: 181-184.

VolTz P. L. 1836. — Das fossile Genus Nerinea. Neues
Jahrbuch für Mineralogie, Geologie und Petrefactenkunde von Leonhard und Bronn: 538-543.

Voltzow J. 1994. - Gastropoda: Prosobranchia, in Harrison F. W. \& Kohn A. J. (eds), Microscopic anatomy of Invertebrates 5, Mollusca 1. Wiley-Liss, New York: 111-152.

Waite R., Wetzel A., Meyer Chr. A. \& Strasser A. 2008. - The paleoecological significance of nerineoid mass accumulations from the Kimmeridgian of the Swiss Jura Mountains. Palaios 23 (8): 548-558.

Weissert H. \& ERba E. 2004. - Volcanism, CO2 and palaeoclimata: a Late Jurassic-Early Cretaceous carbon and oxygen isotope record. Journal of the Geological Society of London 161: 1-8.

WEN Y. 1983. - Cretaceous gastropod assemblages from Xizang (Tibet) with reference to their paleozoogeographical significance. Bolletino della Societá Paleontologica Italiana 22 (1-3): 179-183.

Wenz W. 1938-44. - Allgemeiner Teil und Prosobranchia, in SCHINDEWOLF O. H. (ed.), Handbuch der Palaeozoologie 6/1. Gebrüder Bornträger, Berlin: I-XII+1-1638.

WenZ W. 1947. - Zur Taxonomie der Euthyneura. Archiv für Molluskenkunde 76: 36.

WENZ W. \& ZILCH A. 1959-1960. - Euthyneura in SchindeWolf O. H. (ed.), Handbuch der Palaeozoologie 6/2. Gebrüder Bornträger, Berlin, 834 p.

WieCZOREK J. 1975. - The taxonomy and life environment of the Upper Jurassic nerineid gastropods from genus Fibuloptygmatis Pchelintsev, 1965. Acta Geologica Polonica 25 (1): 153-162.

WIECZOREK J. 1979. - Upper Jurassic nerineacean gastropods from the Holy Cross Mts (Poland). Acta Palaeontologica Polonica 24 (3): 299-350.

WieCZOREK J. 1998. - Nerineaceans from the Ernstbrunn Limestone (Tithonian, Austria). Annalen des Naturhistorischen Museumsy Wien 99A: 311-329.

WiLMSEN M. 2012. - Origin and significance of Late Cretaceous bioevents: Examples from the Cenomanian. Acta Palaeontologica Polonica 57: 759-771.

WoOdRING W. P. 1952. - A Nerinea from southwestern Oriente Province, Cuba. Journal of Paleontology 26 (1): 60-62.

YONGE C. M. 1946. - On the habitats of Turritella communis Risso. Journal of the Marine Biology Association 26: 377-380.

ZitTel K. A. 1873. — Paläontologische Studien über die Grenzschichten der Jura- und Kreideformation. 3. Die Gastropoden der Stramberger Schichten. Paläontologische Mitteilungen aus dem Museum des Königlich Bayerischen Staates 2: 311-490.

Submitted on 7 May 2013; accepted on 20 February 2014; published on 26 September 2014. 
